\title{
Sulfonamide-containing copper(II) metallonucleases: Correlations with in vitro antimycobacterial and antiproliferative activities ${ }^{\text {is }}$
}

\author{
Douglas H. Nakahata ${ }^{a, 1}$, Raphael E.F. de Paiva ${ }^{a, 1}$, Wilton R. Lustri ${ }^{\mathrm{b}}$, Camila M. Ribeiro ${ }^{\mathrm{c}}$, \\ Fernando R. Pavan ${ }^{\mathrm{c}}$, Gisele G. da Silva ${ }^{\mathrm{d}, \mathrm{e}, \mathrm{f}}$, Ana L.T.G. Ruiz ${ }^{\mathrm{d}, \mathrm{e}}$, João E. de Carvalho ${ }^{\mathrm{d}}$, \\ Pedro P. Corbi ${ }^{\mathrm{a}, *}$ \\ ${ }^{a}$ Institute of Chemistry, University of Campinas, UNICAMP, 13083-970 Campinas, SP, Brazil \\ b Biological and Health Sciences Department, University of Araraquara, UNIARA, 14801-320 Araraquara, SP, Brazil \\ ' School of Pharmaceutical Sciences, São Paulo State University, UNESP, 14800-901 Araraquara, SP, Brazil \\ d Faculty of Pharmaceutical Sciences, University of Campinas, UNICAMP, 13081-970 Campinas, SP, Brazil \\ e Chemical, Biological and Agricultural Pluridisciplinary Research Center (CPQBA), University of Campinas - UNICAMP, 13148-218 Paulínia, SP, Brazil \\ f Department of Physiological Sciences, Piracicaba Dental School, University of Campinas, UNICAMP, 13414-903, Piracicaba, SP, Brazil
}

\section{A R T I C L E I N F O}

\section{Keywords:}

Copper(II)

Sulfonamides

Metallonucleases

Antiproliferative activity

Anti-M. tuberculosis activity

\begin{abstract}
A B S T R A C T
The bis-(1,10-phenanthroline)copper(I) complex, $\left[\mathrm{Cu}(\mathrm{I})(\mathrm{phen})_{2}\right]^{+}$, was the first copper-based artificial nuclease reported in the literature. The biological and ligand-like properties of sulfonamides make them good candidates for fine-tuning the reactivity of the $\left[\mathrm{Cu}(\text { phen })_{2}\right]$ motif with biomolecules. In this context, we developed three novel copper(II) complexes containing the sulfonamides sulfameter (smtrH) and sulfadimethoxine (sdmxH) and $\left(\mathrm{N}^{\wedge} \mathrm{N}\right)$-bidentate ligands (2,2'-biyridine or 1,10-phenantroline). The compounds were characterized by chemical and spectroscopic techniques and single-crystal X-ray crystallography. When targeting plasmid DNA, the phencontaining compounds $\left[\mathrm{Cu}\left(\mathrm{smtr}^{-}\right)_{2}\right.$ (phen)] (1) and $\left[\mathrm{Cu}\left(\mathrm{sdmx}^{-}\right)_{2}(\mathrm{phen})\right]$ (2) demonstrated nuclease activity even in the absence of reducing agents. Addition of ascorbic acid resulted in a complete cleavage of DNA by 1 and 2 at concentrations higher than $10 \mu \mathrm{M}$. Experiments designed to evaluate the copper intermediates involved in the nuclease effect after reaction with ascorbic acid identified at least the $\left[\mathrm{Cu}(\mathrm{I})\left(\mathrm{N}^{\wedge} \mathrm{N}\right)_{2}\right]^{+},[\mathrm{Cu}(\mathrm{I})(\mathrm{sulfa})$ $\left.\left(\mathrm{N}^{\wedge} \mathrm{N}\right)\right]^{+}$and $\left[\mathrm{Cu}(\mathrm{I})(\text { sulfa })_{2}\right]^{+}$species. The compounds interact with DNA via groove binding and intercalation as verified by fluorescence spectroscopy, circular dichroism (CD) and molecular docking. The magnitude and preferred mode of binding are dependent on the nature of both $\mathrm{N}^{\wedge} \mathrm{N}$ ligand and the sulfonamide. The potent nuclease activity of compounds $\mathbf{1}$ and $\mathbf{2}$ are well correlated with their antiproliferative and anti-M. tuberculosis profiles. The results presented here demonstrated the potential for further development of copper(II)-sulfonamide-( $\left.\mathrm{N}^{\wedge} \mathrm{N}\right)$ complexes as multipurpose metallodrugs.
\end{abstract}

\section{Introduction}

Artificial nucleases mimic the function of nucleases due to their capability to cleave the DNA phosphate ester bonds. The bis-(1,10phenanthroline)copper(I) complex, $\left[\mathrm{Cu}(\mathrm{I})(\text { phen })_{2}\right]^{+}$was the first copper-based artificial nuclease reported in the literature [1]. The mode of action of $\left[\mathrm{Cu}(\mathrm{phen})_{2}\right]^{2+}$ is based on the generation of reactive oxygen species (ROS) upon reduction in the presence of molecular oxygen or hydrogen peroxide [1-4].

The remarkable nuclease properties of $\left[\mathrm{Cu}(\mathrm{I})(\text { phen })_{2}\right]^{+}$are related to its high DNA binding constants, directly related to the properties of the phen ligand, which gives to the compound the ability to interact with DNA via minor groove-binding [5-7]. The reaction mechanism involves $\mathrm{H}$ atoms $\mathrm{C1}^{\prime}$ and $\mathrm{C} 4$ ' of the deoxyribose, which are located within the minor groove, as the main targets for the oxidative attack [8]. The (bpy)-copper complex (bpy-bipyridine), however, interacts mainly via electrostatic interactions with the negatively charged phosphate backbone [5, 9]. For this reason, the series of $\mathrm{Cu}(\mathrm{II})$ compounds explored in this work was designed to compare the DNAbinding properties of phen and bpy and the effects on the nuclease

\footnotetext{
In celebration of the 70th birthday of Professor Nicholas P. Farrell.

* Corresponding author.

E-mail address: ppcorbi@iqm.unicamp.br (P.P. Corbi).

${ }^{1}$ These authors contributed equally to this manuscript.
} 


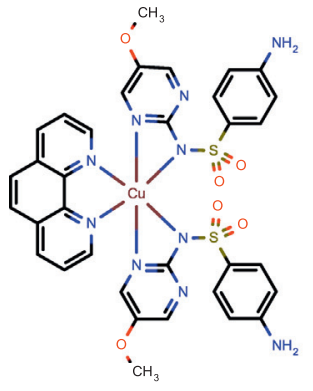

$1\left[\mathrm{Cu}\left(\mathrm{smtr}_{2}\right)_{2}\right.$ (phen) $]$

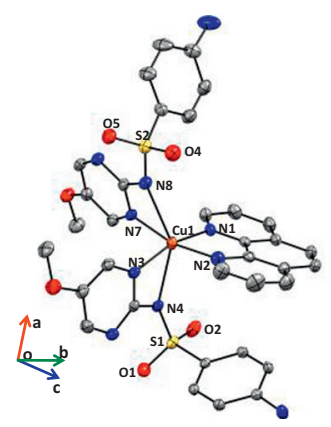

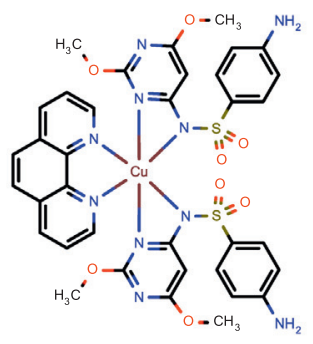

$2\left[\mathrm{Cu}\left(\mathrm{sdmx}^{-}\right)_{2}(\right.$ phen $\left.)\right]$

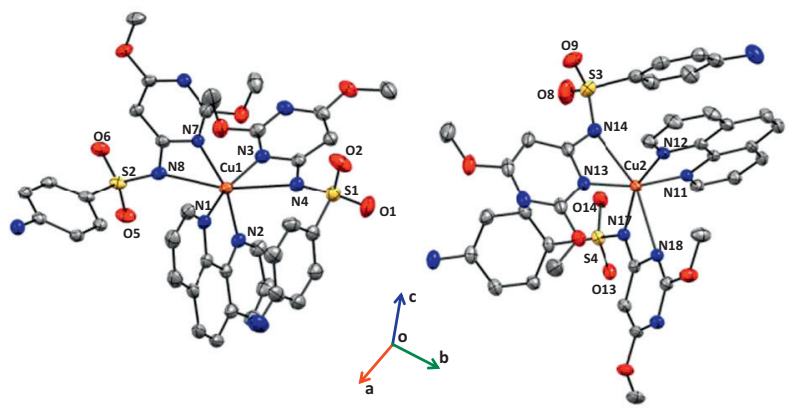

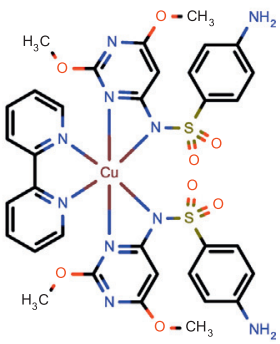

$3\left[\mathrm{Cu}\left(\mathrm{sdmx}^{-}\right)_{2}(\mathrm{bpy})\right]$

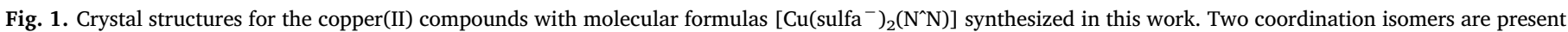
in the asymmetric unit of $\mathbf{2}$. Displacement ellipsoids are drawn at the $40 \%$ probability level. The hydrogen atoms and water molecules were omitted for clarity.

activity of the compounds.

Since the introduction of $\left[\mathrm{Cu}(\mathrm{phen})_{2}\right]^{2+}$, much effort has been dedicated to the development of novel artificial metallonucleases, since metal complexes are endowed with several properties that can be explored to fine-tune the desired nuclease activity. This includes the number and nature of the ligands, structural diversity and electronic properties $[5,7,10]$. For reviews of artificial copper metallonucleases, the reader is directed to the works of McGivern et al. [7] and Pratviel et al. [11]. Mixed chelate copper(II) complexes known as Casiopeinas ${ }^{\circledR}$ are also based on phen and bipy derivatives and possess remarkable antiproliferative activities [12, 13]. Casiopeinas are an excellent example of compounds built around the $\mathrm{Cu}\left(\mathrm{N}^{\wedge} \mathrm{N}\right)$ moiety with variable coligands and demonstrate the importance of the co-ligand on the cytotoxic activity. In the same context, the nuclease activity of [Cu(II) (phen)] and [Cu(II)(bpy)] complexes are also expected to be affected by the introduction of additional ligands, including sulfonamides.

Sulfonamides represent an optimal class of drugs to be used as ligands following this approach since they have interesting structural variety, containing $\mathrm{N}, \mathrm{O}$ and S-donor moieties. In terms of biological activities, sulfonamides are studied in the development of antimicrobial, anticancer and anti-inflammatory drugs [14]. Sulfameter (also known as sulfamethoxidiazine, smtrH), one of the sulfonamides investigated in this work, is used in the treatment of infections of the respiratory and urinary tracts in animals [15]. Sulfadimethoxine (sdmxH), on the other hand, is a long-acting sulfonamide, which is specially used for the treatment of coccidiosis, a parasitic disease of animals [16].

One of the areas of interest for the application of artificial nucleases resides on nucleic acid-targeting therapies. Two DNA-targeting applications are explored in this work. The first one is tuberculosis, which is still among the top 10 causes of death worldwide, according to the latest World Health Organization report on tuberculosis [17]. Copper complexes have been gaining attention as candidates for the development of novel agents for tuberculosis treatment. It has been reported that copper resistance is an important factor for Mycobacterium tuberculosis virulence. In this sense, increasing the intracellular content of bactericidal copper via administration of compounds (named "copperboosting" compounds) that can cross the mycobacterial outer membrane barrier is one approach for the development of novel antituberculosis drugs $[18,19]$. The second biological endpoint tackled here, cancer, is the second largest cause of death worldwide [20]. It is estimated that $75 \%$ of cancer cases occur in low to middle-income countries. For that reason, the development of effective and low cost cancer treatments is of major interest. Since copper is an essential metal for human health, its compounds have been developed as anticancer agents based on the hypothesis that they may be more selective and less toxic [21-23].

Copper complexes with sulfonamides have been explored for a variety of applications, including their superoxide dismutase (SOD)-like and nuclease properties, and antibacterial and anticancer activities. The copper(II) complex containing sdmxH and two ammonia molecules presented antibacterial activity, and it was more active over Gram-positive Staphylococcus aureus strain than over Gram-negative Escherichia coli [24]. However, there are no reports of copper-sulfonamide complexes active over $M$. tuberculosis. Several papers have described the anticancer activities of copper-sulfonamide complexes. González-Álvarez et al., for example, reported copper(II)-bpy complexes with thiazol-sulfonamide derivatives with nuclease activities that correlated with their cytotoxicity on the low micromolar range against human Jurkat T lymphocytes and Caco-2 cell lines. The complexes induced cell death by an apoptotic mechanism [10]. The same research group reported copper complexes of $\mathrm{N}$-substituted sulfonamides that presented DNA photocleavage and remarkable cytotoxicity on sub-micromolar range against Caco-2 cell lines [25]. Such results stimulate the synthesis of new copper(II) sulfonamide complexes and strengthen the potential of application of such compounds also as anticancer drugs.

Within this context, here we report three $\mathrm{Cu}(\mathrm{II})$ coordination compounds with activity over both mycobacteria and cancer cells of general formula $\left[\mathrm{Cu}\left(\mathrm{sulfa}^{-}\right)_{2}\left(\mathrm{~N}^{\wedge} \mathrm{N}\right)\right]$, where sulfa ${ }^{-}$is the anionic form of a sulfonamide ligand (sulfameter or sulfadimethoxine) and the $\left(\mathrm{N}^{\wedge} \mathrm{N}\right)$ bidentate ligand is $2,2^{\prime}$-bipyridine (bpy) or 1,10-phenanthroline (phen), see Fig. 1 . The bpy and phen ligands are explored to compare the effect of different DNA-binding modes (electrostatic interaction vs. minor groove binding) on the nuclease activity of the designed copper(II) compounds. 


\section{Experimental section}

\subsection{Materials and methods}

Copper nitrate trihydrate (99-104\%), sulfameter (smtrH, 99\%), sulfadimethoxine ( $\mathrm{sdmxH}, \geq 98.5 \%$ ), 2,2'-bipyridine (bpy, $\geq 98.0 \%$ ), DNA sodium salt from calf-thymus type I ( $42 \%$ of guanine-cytosine) were obtained from Sigma. The 1,10-phenanthroline monohydrate (phen, 99.5\%) ligand was acquired from Vetec.

Elemental analyses were performed on a Perkin Elmer 2400 CHNS/ O Analyzer. Electronic spectra in the $190-1100 \mathrm{~nm}$ range were acquired by using a $1.0 \mathrm{~cm}$ quartz cuvette in a diode array HP8453 UV/Visible absorption spectrophotometer. Electrospray ionization mass spectrometric (ESI-MS) measurements were carried out using a Waters Synapt HDMS (Manchester, UK). The samples were evaluated in the positive mode. Each solution was directly infused into the instrument's ESI source with $30 \mu \mathrm{L} \cdot \mathrm{min}^{-1}$ of infusion rate, capillary potential of $3.75 \mathrm{kV}$, cone voltage of $30 \mathrm{~V}$, source temperature of $120^{\circ} \mathrm{C}$ and dessolvation temperature of $150^{\circ} \mathrm{C}$. The NMR spectra were recorded in a Bruker Avance III $500 \mathrm{MHz}$ spectrometer (11.7 T). X-ray powder diffractograms were acquired on a Shimadzu XRD7000, with a copper tube operating at $40 \mathrm{kV}$ and $30 \mathrm{~mA}$. The scanning was performed on continuous mode, from 5 to $50^{\circ}(2 \theta)$ and scanning speed of $2^{\circ} \mathrm{min}^{-1}$. Fluorescence measurements were performed on a Cary Eclipse fluorescence spectrophotometer using a quartz cuvette of four clear windows and optical path length of $1.0 \mathrm{~cm}$. Excitation and emission slits were of $5 \mathrm{~nm}$ and scanning speed was set to medium. Circular dichroism measurements were performed in a Jasco J-720 spectrophotometer, in quartz cuvettes of $1.0 \mathrm{~cm}$ of optical path length.

\subsection{Syntheses of the copper(II) compounds}

The three compounds were prepared using the same method. In summary, a methanolic solution of phen or bpy $(0.25 \mathrm{mmol}$ dissolved in $3.0 \mathrm{~mL}$ ) was added to an aqueous solution containing $\mathrm{Cu}\left(\mathrm{NO}_{3}\right)_{2} \cdot 3 \mathrm{H}_{2} \mathrm{O}$ $(0.25 \mathrm{mmol}, 1.0 \mathrm{~mL})$ and kept under stirring for $1 \mathrm{~h}$. Separately, a solution of deprotonated sulfameter or sulfadimethoxine $(0.50 \mathrm{mmol}$, $3.0 \mathrm{~mL}$ of water plus $3.0 \mathrm{~mL}$ of methanol) was prepared by the addition of ammonium hydroxide to the sulfa suspension until solubilization. Then, the copper-phen or copper-bpy solution was added to the solution containing the deprotonated sulfonamide. The reactions were maintained under stirring at room temperature for $4 \mathrm{~h}$.

$\left[\mathrm{Cu}\left(\mathrm{smtr}^{-}\right)_{2}\right.$ (phen) $] \cdot 3 \mathrm{H}_{2} \mathrm{O}$

The green powder obtained was collected by filtration, washed with cold methanol and dried under vacuum. Found (\%): C, 48.1; H, 3.94; N, 16.4. Calc. for [ $\left.\mathrm{Cu}\left(\mathrm{C}_{11} \mathrm{H}_{11} \mathrm{~N}_{4} \mathrm{O}_{3} \mathrm{~S}\right)_{2}\left(\mathrm{C}_{12} \mathrm{H}_{8} \mathrm{~N}_{2}\right)\right] \cdot 3 \mathrm{H}_{2} \mathrm{O}$ (\%): C, 47.7; $\mathrm{H}$, 4.24; $\mathrm{N}, 16.4$. Yield: $0.0920 \mathrm{~g}, 40 \%$. $\lambda_{\max }$ (phosphate buffer, $\mathrm{pH}=7.4$, $10 \mathrm{mM}): 201 \mathrm{~nm}\left(\varepsilon 83,400 \mathrm{M}^{-1} \cdot \mathrm{cm}^{-1}\right), 232 \mathrm{~nm}\left(\varepsilon 54,400 \mathrm{M}^{-1} \cdot \mathrm{cm}^{-1}\right)$, $262 \mathrm{~nm}\left(\varepsilon 59,300 \mathrm{M}^{-1} \cdot \mathrm{cm}^{-1}\right), 292 \mathrm{~nm}\left(\varepsilon 17,600 \mathrm{M}^{-1} \cdot \mathrm{cm}^{-1}\right)$ and $326 \mathrm{~nm}\left(\varepsilon 5600 \mathrm{M}^{-1} \cdot \mathrm{cm}^{-1}\right)$. Green single-crystals suitable for X-ray diffraction measurements were obtained by recrystallization from a 10:1 methanol:water solution.

$\left[\mathrm{Cu}\left(\mathrm{sdmx}^{-}\right)_{2}\right.$ (phen) $] \cdot \mathrm{H}_{2} \mathrm{O}$

No solid was obtained after the $4 \mathrm{~h}$ of reaction. Then, an aliquot of the dark-green solution was left to stand at room temperature while the remaining solution was rotaevaporated to dryness. Further, $20.0 \mathrm{~mL}$ of ethanol were added to the solid and this system was heated to boiling. After cooling, the solid was separated by filtration and dried under vacuum. Found (\%): $\mathrm{C}, 48.4 ; \mathrm{H}, 4.02 ; \mathrm{N}, 15.8$. Calc. for $[\mathrm{Cu}$ $\left.\left(\mathrm{C}_{12} \mathrm{H}_{13} \mathrm{~N}_{4} \mathrm{O}_{4} \mathrm{~S}\right)_{2}\left(\mathrm{C}_{12} \mathrm{H}_{8} \mathrm{~N}_{2}\right)\right] \cdot \mathrm{H}_{2} \mathrm{O}$ (\%): C, 48.6; $\mathrm{H}, 4.19 ; \mathrm{N}, 15.8$. Yield: $0.1284 \mathrm{~g}, 58 \% . \lambda_{\max }$ (phosphate buffer, $\left.\mathrm{pH}=7.4,10 \mathrm{mM}\right): 203 \mathrm{~nm}(\varepsilon$ $\left.89,700 \mathrm{M}^{-1} \cdot \mathrm{cm}^{-1}\right), \quad 231 \mathrm{~nm}\left(\varepsilon 36,500 \mathrm{M}^{-1} \cdot \mathrm{cm}^{-1}\right)$ and $270 \mathrm{~nm}(\varepsilon$ $65,000 \mathrm{M}^{-1} \cdot \mathrm{cm}^{-1}$ ). Green single-crystals suitable for X-ray diffraction measurements were obtained from the dark-green solution after a few days of standing.

$\left[\mathrm{Cu}\left(\mathrm{sdmx}^{-}\right)_{2}(\mathrm{bpy})\right]$

The light green powder obtained was separated by filtration, washed with cold methanol and dried under vacuum. Found (\%): C, 48.5; $\mathrm{H}, 4.01 ; \mathrm{N}, 16.7$. Calc. for $\left[\mathrm{Cu}\left(\mathrm{C}_{12} \mathrm{H}_{13} \mathrm{~N}_{4} \mathrm{O}_{4} \mathrm{~S}\right)_{2}\left(\mathrm{C}_{10} \mathrm{H}_{8} \mathrm{~N}_{2}\right)\right]$ (\%): C, 48.7; $\mathrm{H}, 4.09 ; \mathrm{N}, 16.7$. Yield: $0.1474 \mathrm{~g}, 70 \%$. $\lambda_{\max }$ (phosphate buffer, $\mathrm{pH}=7.4, \quad 10 \mathrm{mM}) \quad 198 \mathrm{~nm} \quad\left(\varepsilon \quad 99,700 \mathrm{M}^{-1} \cdot \mathrm{cm}^{-1}\right), \quad 257 \mathrm{~nm} \quad(\varepsilon$ $\left.48,700 \mathrm{M}^{-1} \cdot \mathrm{cm}^{-1}\right), \quad 269 \mathrm{~nm} \quad\left(\varepsilon \quad 52,800 \mathrm{M}^{-1} \cdot \mathrm{cm}^{-1}\right), \quad 299 \mathrm{~nm} \quad(\varepsilon$ $\left.16,600 \mathrm{M}^{-1} \cdot \mathrm{cm}^{-1}\right)$ and $311 \mathrm{~nm}\left(\varepsilon 13,000 \mathrm{M}^{-1} \cdot \mathrm{cm}^{-1}\right)$. Green singlecrystals suitable for X-ray diffraction measurements were obtained by slow evaporation of the supernatant from the synthesis.

The diffractograms of polycrystalline samples of the complexes were compared to the ones calculated from the single-crystals to confirm if they match. The results confirm the same structures of the complexes in powder and crystals forms (see Supporting Information, Figs. S1-S3). Since good agreements were observed, the polycrystalline samples were used for all analyses.

\subsection{Single-crystal $X$-ray diffraction}

Data collections for the single crystals of compounds 1-3 and for $\{[\mathrm{Cu}(\mathrm{II}) \text { (oxalate)(phen) }] \cdot 2 \mathrm{dmso}\}_{\mathrm{n}}$ were performed with a Bruker Apex II CCD diffractometer with graphite monochromated $\mathrm{Cu}-\mathrm{K} \alpha$ $(\lambda=1.5418 \AA)$ radiation. Unit cell dimensions and orientation matrices were determined by least squares refinement of the reflections obtained by $\theta-\chi$ scans. The data were indexed and scaled with the ApexII Suite. Bruker SAINT and SADABS were used to integrate and for absorption correction, respectively [26]. The structure was solved with ShelXS using direct methods and refined with ShelXL [27] in Olex2 [28]. All nonhydrogen atoms were refined anisotropically, with exception of the oxygen atoms from the water molecules of compound 2 . The occupancies of two of the water molecules present in the crystal structure of compound 2 were refined for optimal values of 0.70 and 0.60 . The solvent disorder in the crystal structure of $\mathbf{2}$ is responsible for most of the alerts (B, C and G) in the corresponding checkCIF file. The hydrogen atoms were added to the structure in idealized positions and refined according to the riding model. Molecular graphics were obtained using Mercury (v. 3.9) [29]. The databank surveys were performed on the Cambridge Structural Database (CSD, v. 5.38, May 2017) [30]. Crystallographic information for compounds 1-3 can be found in Table 1, while for $\left\{[\mathrm{Cu}(\mathrm{II})(\text { oxalate)(phen) }] \cdot 2 \mathrm{dmso}\}_{\mathrm{n}}\right.$, data can be found in Supporting Information, Table S1.

\subsection{Assessment of nuclease activity by agarose gel electrophoresis}

These experiments were performed according to previously reported procedures, with some adaptations [10, 31, 32]. For the interaction of the compounds with plasmid DNA, samples of the three copper(II) complexes and copper(II) nitrate (for comparison) at different concentrations $(13,26,39$ and $52 \mu \mathrm{M})$ were incubated with pGEX-4T1 plasmid (18 $\mu \mathrm{g}$ per sample, estimated spectrophotometrically [33]) in phosphate buffer $10 \mathrm{mM}$ (pH $=7.4$ ), for a final sample volume of $20 \mu \mathrm{L}$. The samples were incubated for $12 \mathrm{~h}$ at $37^{\circ} \mathrm{C}$ and after that, $5 \mu \mathrm{L}$ of loading buffer (30 mM EDTA, 30\% glycerol, $0.25 \%$ xylene cyanol and $0.25 \%$ bromophenol blue) were added. A volume of $15 \mu \mathrm{L}$ of each of these mixtures was loaded onto an agarose gel $(0.8 \%)$ and submitted to electrophoresis $(100 \mathrm{~V})$ in TBE buffer $(45 \mathrm{mM}$ Tris/borate, $\mathrm{pH}=8.3$, $1 \mathrm{mM}$ EDTA). Gel staining was performed in a SYBR green solution (diluted in TBE buffer, final pH 8.0) and bands were visualized under UV light.

To test the DNA cleavage ability of the complexes in the presence of a reducing agent, the compounds (at concentrations of $1,5,10$ and $20 \mu \mathrm{M}$ ) were incubated with pGEX-4T1 plasmid ( $18 \mu \mathrm{g}$ per sample) in the presence of an excess of ascorbic acid $(1 \mathrm{mM})$. The samples were incubated for $1 \mathrm{~h}$ at $37^{\circ} \mathrm{C}$ and submitted to electrophoresis as described above. 
Table 1

Crystallographic details for the structures of $1-3$.

\begin{tabular}{|c|c|c|c|}
\hline Complex & 1 & $2^{\mathrm{a}}$ & 3 \\
\hline Empirical formula & $\mathrm{C}_{34} \mathrm{H}_{30} \mathrm{CuN}_{10} \mathrm{O}_{6} \mathrm{~S}_{2} \cdot 3 \mathrm{H}_{2} \mathrm{O}$ & $\mathrm{C}_{36} \mathrm{H}_{34} \mathrm{CuN}_{10} \mathrm{O}_{8} \mathrm{~S}_{2} \cdot 1.15 \mathrm{H}_{2} \mathrm{O}^{\mathrm{a}}$ & $\mathrm{C}_{34} \mathrm{H}_{34} \mathrm{CuN}_{10} \mathrm{O}_{8} \mathrm{~S}_{2}$ \\
\hline Formula weight $\left(\mathrm{g} \cdot \mathrm{mol}^{-1}\right)$ & 856.39 & $883.11^{\mathrm{a}}$ & 838.37 \\
\hline $\mathrm{T}(\mathrm{K})$ & 150 & 150 & 150 \\
\hline$\lambda\left(\mathrm{CuK}_{\alpha}\right)(\AA)$ & 1.5418 & 1.5418 & 1.5418 \\
\hline Crystal system & Orthorhombic & Monoclinic & Monoclinic \\
\hline Space group & $\mathrm{Pbca}$ & $P 2_{1} / c$ & $P 2_{1} / c$ \\
\hline$a(\AA)$ & $20.8949(17)$ & $16.3408(5)$ & $16.1884(5)$ \\
\hline$b(\AA)$ & $15.8276(11)$ & $42.6934(15)$ & $16.8210(5)$ \\
\hline$c(\AA)$ & $22.6355(16)$ & $11.5804(4)$ & $14.1666(4)$ \\
\hline$\beta\left(^{\circ}\right)$ & 90 & $103.900(2)$ & $109.150(2)$ \\
\hline $\mathrm{V}\left(\AA^{3}\right)$ & $7485.9(10)$ & $7842.4(5)$ & 3644.17 (19) \\
\hline $\mathrm{Z}$ & 8 & 8 & 4 \\
\hline $\mathrm{d}_{\text {calc }}\left(\mathrm{g} \cdot \mathrm{cm}^{-3}\right)$ & 1.520 & 1.496 & 1.528 \\
\hline$\mu\left(\mathrm{mm}^{-1}\right)$ & 2.45 & 2.36 & 2.49 \\
\hline$\theta\left({ }^{\circ}\right)$ & $3.906-66.590$ & $2.972-66.595$ & $2.889-67.823$ \\
\hline $\mathrm{F}(000)$ & 3544 & 3652 & 1732 \\
\hline Reflections collected & 37,892 & 39,597 & 25,277 \\
\hline Independent reflections & 6578 & 13,381 & 6412 \\
\hline Data/restraints/parameters & $6578 / 6 / 539$ & $13,381 / 7 / 1060$ & $6412 / 0 / 516$ \\
\hline Goodness-of-fit on $F^{2}$ & 1.17 & 1.12 & 1.02 \\
\hline $\mathrm{R}_{1}, \mathrm{wR}_{2}[I>2 \sigma(\mathrm{I})]$ & $0.048,0.121$ & $0.054,0.132$ & $0.032,0.081$ \\
\hline Largest diffraction peak and hole $\left(\mathrm{e} \cdot \AA^{-3}\right)$ & $0.63 /-0.52$ & $0.89 /-0.66$ & $0.28 /-0.45$ \\
\hline
\end{tabular}

a These values take into account only one of copper sites present in the crystal structure and half of the water molecules.

In order to identify possible ROS responsible for the observed DNA cleavage in the presence of ascorbic acid, samples of the pGEX-4T1 plasmid ( $18 \mu \mathrm{g}$ per sample) were incubated with ROS scavengers dmso $(10 \%), \mathrm{NaN}_{3}(50 \mathrm{mM}), \mathrm{KI}(50 \mathrm{mM})$ and catalase $\left(100 \mu \mathrm{g} \cdot \mathrm{mL}^{-1}\right)$ for $10 \mathrm{~min}$ at $37^{\circ} \mathrm{C}$. Afterwards, the complexes $(20 \mu \mathrm{M})$ and ascorbic acid $(1 \mathrm{mM})$ were added to the samples and these mixtures were further incubated for $1 \mathrm{~h}$ at $37^{\circ} \mathrm{C}$. Electrophoresis was carried out as described above.

Image acquisition: The gels were placed on a UV-transilluminator inside a dark chamber. Images were acquired using a Canon T5i photographic camera and an $18-55 \mathrm{~mm}$ lens equipped with an adequate filter for the SYBR green stain.

Image processing: Images were pre-processed in the Image $1.51 \mathrm{j} 8$ software. The images were stacked to black and white and the contrast was adjusted. The lookup table was inverted, producing images with dark bands in a bright background. Finally, dark outlier noise was removed (radius of 10 pixels, threshold of 50). High resolution tif files were then exported.

Plasmid cleavage quantification: Tif images were imported to Image Lab 6.0.0 build 25 (Bio-Rad laboratories). Total plasmid cleavage induced by the $\mathrm{Cu}(\mathrm{II})$ series in presence of different scavengers was analyzed per lane, in comparison to the adjusted total lane volume of the untreated control.

\subsection{Probing the molecular mechanism of nuclease activity - Investigation of the reaction with ascorbic acid}

\subsubsection{Mass spectrometry}

Fresh stock solutions of ascorbic acid were prepared in a water/ acetonitrile $1: 1$ mixture containing $0.1 \%$ formic acid. Stock solutions of the three copper(II) complexes $(100 \mu \mathrm{M})$ were prepared in the same solvent mixture, but with further addition of dimethylformamide $(0.1 \%)$. Measurements were performed by the reaction of $1.0 \mathrm{~mL}$ of the reducing agent with $1.0 \mathrm{~mL}$ of the complexes (final concentration of both reactants of $50 \mu \mathrm{M})$. Each reaction was prepared directly before the infusion into the ESI source of the instrument. The samples were handled under atmospheric conditions (aerobic). The measurements were repeated after $24 \mathrm{~h}$ of reaction.

\subsubsection{Nuclear magnetic resonance (NMR)}

The NMR spectra of phen, sulfameter, ascorbic acid and compound $\mathbf{1}$ were acquired in dmso-d6. The reaction of compound $\mathbf{1}$ and ascorbic acid was carried out in dmso-d6, with final concentrations of the reactants of $10 \mathrm{mM}$ and final volume of $500 \mu \mathrm{L}$. The ${ }^{1} \mathrm{H}$ NMR spectra were acquired in intervals of $90 \mathrm{~s}$ for $30 \mathrm{~min}$.

\subsubsection{Crystallography}

Single-crystals suitable for crystallographic studies appeared in the NMR tube where the reaction of compound $\mathbf{1}$ and ascorbic acid was performed after approximately 20 days. Crystallographic data for this compound can be found in Supporting Information, Table S1.

\subsection{General DNA binding in the absence of reducing agents}

\subsubsection{Preparation of the calf-thymus DNA (CT-DNA) stock solution}

Stock solutions of calf-thymus DNA were prepared by dialysis of samples dissolved in $10 \mathrm{mM} \mathrm{PB}(\mathrm{pH}=7.4)$ for $24 \mathrm{~h}$. The concentrations of the prepared solutions were measured by considering the $\varepsilon$ value at $260 \mathrm{~nm}$ of $6600 \mathrm{~L} \cdot \mathrm{mol}^{-1} \cdot \mathrm{cm}^{-1}$.

\subsubsection{Fluorescence spectroscopy - Competitive DNA binding}

Stock solutions of CT-DNA $(100 \mu \mathrm{M})$ in PB $(10 \mathrm{mM})$ were mixed with either ethidium bromide (EB, $25 \mu \mathrm{M})$ or Hoechst 33,258 $(1.0 \mu \mathrm{M})$. Then, $2.0 \mathrm{~mL}$ of either stock solutions were transferred to a cuvette and the samples were titrated with solutions of the title compounds (prepared at $1 \mathrm{mM}$ in $\mathrm{PB}$ containing 10\% dmso), without idle time between additions. For EB, excitation was set to $525 \mathrm{~nm}$ and emission data were collected from 545 to $700 \mathrm{~nm}$ (maximum at $603 \mathrm{~nm}$ ). The excitation wavelength containing Hoechst was set to $350 \mathrm{~nm}$ and emission data were collected from 400 to $550 \mathrm{~nm}$ (maximum at $460 \mathrm{~nm}$ ). Measurements were performed at $37^{\circ} \mathrm{C}$ in triplicate. The data from the Hoechst system were smoothed according to the Savitzky-Goley treatment to improve curve resolution. The data were treated according to the Stern-Volmer equation.

\subsubsection{Circular dichroism spectroscopy}

Samples of CT-DNA (fixed concentration of $100 \mu \mathrm{M}$ ) in $10 \mathrm{mM} \mathrm{PB}$ ( $\mathrm{pH}=7.4$ ) were incubated with the copper(II) complexes for different [compound]/[DNA] ratios (ranging from 0 to 0.30 ; final volume $2.0 \mathrm{~mL})$, at $37^{\circ} \mathrm{C}$ and for $24 \mathrm{~h}$. The stock solutions of $1-3(100 \mu \mathrm{M})$ were prepared in $\mathrm{PB}(10 \mathrm{mM}, \mathrm{pH}=7.4)$. The spectra were recorded with scanning speed of $50 \mathrm{~nm} \cdot \min ^{-1}$ with 8 accumulations and at $37^{\circ} \mathrm{C}$. 
Table 2

Selected bond lengths $(\AA)$ and angles $\left({ }^{\circ}\right)$ of complexes 1, 2 and 3.

\begin{tabular}{|c|c|c|c|c|c|c|c|}
\hline \multicolumn{2}{|c|}{$\left[\mathrm{Cu}\left(\mathrm{smtr}^{-}\right)_{2}(\mathrm{phen})\right](\mathbf{1})$} & \multicolumn{4}{|c|}{$\left[\mathrm{Cu}\left(\mathrm{sdmx}^{-}\right)_{2}(\mathrm{phen})\right](\mathbf{2})$} & \multicolumn{2}{|c|}{$\left[\mathrm{Cu}\left(\mathrm{sdmx}^{-}\right)_{2}\right.$ (bpy)] (3) } \\
\hline $\mathrm{Cu} 1-\mathrm{N} 1$ & $2.025(2)$ & $\mathrm{Cu} 1-\mathrm{N} 1$ & $2.032(3)$ & $\mathrm{Cu} 2-\mathrm{N} 11$ & $2.025(3)$ & $\mathrm{Cu} 1-\mathrm{N} 1$ & $2.023(2)$ \\
\hline $\mathrm{Cu} 1-\mathrm{N} 2$ & $2.015(3)$ & $\mathrm{Cu} 1-\mathrm{N} 2$ & $2.011(3)$ & $\mathrm{Cu} 2-\mathrm{N} 12$ & $2.029(3)$ & $\mathrm{Cu} 1-\mathrm{N} 2$ & $2.005(2)$ \\
\hline $\mathrm{Cu} 1-\mathrm{N} 3$ & $2.027(2)$ & $\mathrm{Cu} 1-\mathrm{N} 3$ & $2.017(3)$ & $\mathrm{Cu} 2-\mathrm{N} 13$ & $2.005(3)$ & $\mathrm{Cu} 1-\mathrm{N} 3$ & $1.991(2)$ \\
\hline $\mathrm{Cu} 1-\mathrm{N} 4$ & $2.388(2)$ & Cu1-N4 & $2.437(3)$ & $\mathrm{Cu} 2-\mathrm{N} 14$ & $2.406(4)$ & $\mathrm{Cu} 1-\mathrm{N} 4$ & $2.626(2)$ \\
\hline $\mathrm{Cu} 1-\mathrm{N} 7$ & $1.969(3)$ & $\mathrm{Cu} 1-\mathrm{N} 7$ & $2.000(3)$ & $\mathrm{Cu} 2-\mathrm{N} 17$ & $2.005(3)$ & $\mathrm{Cu} 1-\mathrm{N} 7$ & $1.986(2)$ \\
\hline $\mathrm{Cu} 1-\mathrm{N} 8$ & $2.583(3)$ & $\mathrm{Cu} 1-\mathrm{N} 8$ & $2.501(3)$ & Cu2-N18 & $2.611(3)$ & $\mathrm{Cu} 1-\mathrm{N} 8$ & $2.571(2)$ \\
\hline $\mathrm{N} 1-\mathrm{Cu} 1-\mathrm{N} 2$ & $81.8(1)$ & $\mathrm{N} 1-\mathrm{Cu} 1-\mathrm{N} 2$ & $81.8(1)$ & $\mathrm{N} 11-\mathrm{Cu} 1-\mathrm{N} 12$ & $81.5(1)$ & $\mathrm{N} 1-\mathrm{Cu} 1-\mathrm{N} 2$ & $80.73(7)$ \\
\hline N3-Cu1-N4 & $60.17(9)$ & N3-Cu1-N4 & $58.9(1)$ & N13-Cu1-N14 & $59.6(1)$ & N3-Cu1-N4 & $56.47(6)$ \\
\hline N8-Cu1-N10 & $57.96(9)$ & N8-Cu1-N10 & $58.6(1)$ & $\mathrm{N} 18-\mathrm{Cu} 1-\mathrm{N} 20$ & $57.0(1)$ & N8-Cu1-N10 & $57.96(6)$ \\
\hline $\mathrm{N} 1-\mathrm{Cu} 1-\mathrm{N} 3$ & $161.4(1)$ & $\mathrm{N} 1-\mathrm{Cu} 1-\mathrm{N} 3$ & $164.0(1)$ & $\mathrm{N} 11-\mathrm{Cu} 1-\mathrm{N} 13$ & $166.0(1)$ & $\mathrm{N} 1-\mathrm{Cu} 1-\mathrm{N} 3$ & $162.46(7)$ \\
\hline $\mathrm{N} 2-\mathrm{Cu} 1-\mathrm{N} 7$ & $164.9(1)$ & N2-Cu1-N7 & $162.6(1)$ & $\mathrm{N} 12-\mathrm{Cu} 1-\mathrm{N} 17$ & $155.7(1)$ & $\mathrm{N} 2-\mathrm{Cu} 1-\mathrm{N} 7$ & 160.57 (7) \\
\hline $\mathrm{N} 4-\mathrm{Cu} 1-\mathrm{N} 8$ & $144.58(8)$ & $\mathrm{N} 4-\mathrm{Cu} 1-\mathrm{N} 8$ & $163.0(1)$ & N14-Cu1-N18 & $158.3(1)$ & $\mathrm{N} 4-\mathrm{Cu} 1-\mathrm{N} 8$ & $161.86(6)$ \\
\hline
\end{tabular}

\subsection{Molecular docking}

Ligand-receptor docking calculations were run using the Schrodinger Suit 2017-2. Ligands and biomolecules were prepared using Maestro 11.2. Coordination bonds were treated as zero-order bonds, and formal charges were adjusted accordingly. No post-docking minimization was used.

Two DNA structures were selected as receptors. A short-length sequence known as Dickerson-Drew Dodecamer 5'-(CGCGAATTCGCG)-3' was picked as a representative B DNA model (PDB ID 4C64). In addition, to better represent a possible intercalation, the formalism described by Ricci et al. [34] was used. Since no crystal structures of DNA with $\left[\mathrm{Cu}(\text { phen })_{2}\right]^{2+}$ are reported, a structure containing DNA and the representative analog $\left[\mathrm{Ru}(\mathrm{phen})_{2}(\mathrm{dppz})\right]^{2+}$ was selected (PDB ID 4LY2). The intercalator was removed and the DNA structure $5^{\prime}$-(TCG GTACCGA)-3' still with the gap induced by the intercalator was used as a receptor model. Ligand sampling was set to flexible. Epik state penalties were added to the docking score. Receptor grids were prepared for each DNA molecule considered, comprising the whole biomolecules. Ten poses returned per ligand and were inspected manually.

\subsection{Anti-M. tuberculosis assay}

The activities of the title copper(II) complexes and of the starting materials over Mycobacterium tuberculosis H37Rv (ATCC 27294) were determined by the REMA (Resazurin Microtiter Plate Assay) method [35] in a 96-well microplate. The stock solutions of $\mathrm{Cu}\left(\mathrm{NO}_{3}\right)_{2} \cdot 3 \mathrm{H}_{2} \mathrm{O}$, and of the three complexes were prepared in water, while those of bpy, phen, the sulfonamides and standard antibiotics were prepared in dmso. The tested concentrations were in the range of 25 to $0.098 \mu \mathrm{g} \cdot \mathrm{mL}$. M. tuberculosis was cultivated in 7H9 (Difco) media supplemented with OADC (oleic acid, albumin, dextrose and catalase) for 7-10 days, at $37^{\circ} \mathrm{C}$, until reaching a value of $1.0 \mathrm{McF}$ arland scale. This suspension was then diluted to the concentration of $2 \times 10^{5} \mathrm{CFU} \cdot \mathrm{mL}^{-1}$. This inoculum $(100 \mu \mathrm{L})$ was then added to $100 \mu \mathrm{L}$ of the tested molecules at different concentration values. The samples were incubated at $37{ }^{\circ} \mathrm{C}$ for seven days. After this period of incubation, $30 \mu \mathrm{L}$ of a resazurin solution $(0.01 \%$ in sterile distilled water) were added to all wells, followed by incubation at $37^{\circ} \mathrm{C}$ for $24 \mathrm{~h}$. The readings were performed on a BioTek Cytation 5 Cell Imaging Multi-Mode Reader spectrophotometer at wavelengths 530/570 $\mathrm{nm}$ (excitation/ emission). The results are given as $\mathrm{MIC}_{90}$, the lowest concentration of drug capable of inhibiting $90 \%$ of growth compared to the positive control.

\subsection{Antiproliferative assays over human tumor cells}

The antiproliferative activity of $\mathrm{Cu}\left(\mathrm{NO}_{3}\right)_{2} \cdot 3 \mathrm{H}_{2} \mathrm{O}$, the free ligands and the copper(II) complexes 1-3 were investigated over nine human tumor cell lines [U251 (glioma), MCF-7 (breast), NCI-ADR/RES (ovarian expressing phenotype of multiple drugs resistance), 786-O (kidney), NCI-H460 (lung, non-small cells), PC-3 (prostate), OVCAR-03 (ovarian), HT-29 (colon adenocarcinoma) and K-562 (chronic myeloid leukemia)], kindly provided by Frederick Cancer Research \& Development Center, National Cancer Institute, Frederick, MA, USA, besides one non-tumor cell line HaCat (human keratinocyte), provided by Dr. Ricardo Della Coletta (University of Campinas, UNICAMP, Brazil) [36, 37]. Stock cultures were grown in $5 \mathrm{~mL}$ of RPMI-1640 supplemented with $5 \%$ fetal bovine serum (RPMI/FBS 5\% Gibco1, USA) and $1 \%$ penicillin:streptomycin mixture (complete medium) at $37{ }^{\circ} \mathrm{C}$ in $5 \% \mathrm{CO}_{2}$. The stock solutions of the samples were prepared directly in complete medium at $5 \mathrm{mg} \cdot \mathrm{mL}^{-1}$ and then diluted in the same medium, affording final concentrations of $0.25,2.5,25$ and $250 \mu \mathrm{g} \cdot \mathrm{mL}^{-1}$. Doxorubicin (final concentrations of $0.025,0.25,2.5$ and $25 \mu \mathrm{g} \cdot \mathrm{mL}^{-1}$ ) was used as control.

For the experiment, cells in 96 -well plates $(100 \mu \mathrm{L}$ cells/well, inoculation density: 3.5 to $6 \times 10^{4}$ cells $/ \mathrm{mL}$ ) were exposed to different concentrations of each sample $(100 \mu \mathrm{L} /$ well $)$ in triplicate, for $48 \mathrm{~h}$ at $37^{\circ} \mathrm{C}$ and $5 \%$ of $\mathrm{CO}_{2}$. Before (T0 plate) and after the sample addition (T1 plates), cells were fixed with 50\% trichloroacetic acid, and cell proliferation was determined by spectrophotometric quantification (at $540 \mathrm{~nm}$ ) of cellular protein content. The TGI values (concentration for complete inhibition of cell proliferation), expressed in $\mu \mathrm{M}$, were determined through nonlinear regression, type sigmoidal, analyzed using Origin 8.0 software (OriginLab Corporation, USA).

\section{Results and discussion}

\subsection{X-ray crystallographic studies}

Complex 1 crystallized in the orthorhombic crystal system (Pbca space group), whereas 2 and 3 crystallized in the monoclinic crystal system (both $P 2_{1} / c$ space group). The crystal structures were shown in Fig. 1, while selected bond lengths and angles are presented in Table 2.

The crystal structures of $\mathbf{1}$ and $\mathbf{3}$ consist of distinct monomeric units, containing the $\left[\mathrm{Cu}\left(\mathrm{sulfa}^{-}\right)_{2}\left(\mathrm{~N}^{\wedge} \mathrm{N}\right)\right]$ moiety. However, the coordination mode of the sulfonamides to $\mathrm{Cu}(\mathrm{II})$ is distinct for each complex. For 1, both axial sites are occupied by nitrogen atoms of the deprotonated sulfonamide group (N4 and N8, Fig. 1), while for 3, one site is occupied by the nitrogen of the sulfonamide group (N4, Fig. 1) and the other by one of the nitrogen atom of the substituted pyrimidinyl group (N8, Fig. 1).

Curiously, the crystal structure of 2 , which is formed by two sdmx ${ }^{-}$ ligands and one phen, presents both coordination modes from 1 and 3 described above. The asymmetric unit of $\mathbf{2}$ is described by two mononuclear copper complexes, in which the first complex (Cu1 site) has both axial sites occupied by the nitrogen atoms of the deprotonated sulfonamide group (N4 and N8, Fig. 1). The second copper site (labeled as $\mathrm{Cu} 2$ ) is similar to the structure observed for $\mathbf{3}$, since it has one axial site occupied by N14 (sulfonamide) and the other by N18 (pyrimidinyl).

The magnitude of the axial $\mathrm{Cu}-\mathrm{N}$ lengths (average $2.5 \AA$ ) for the 

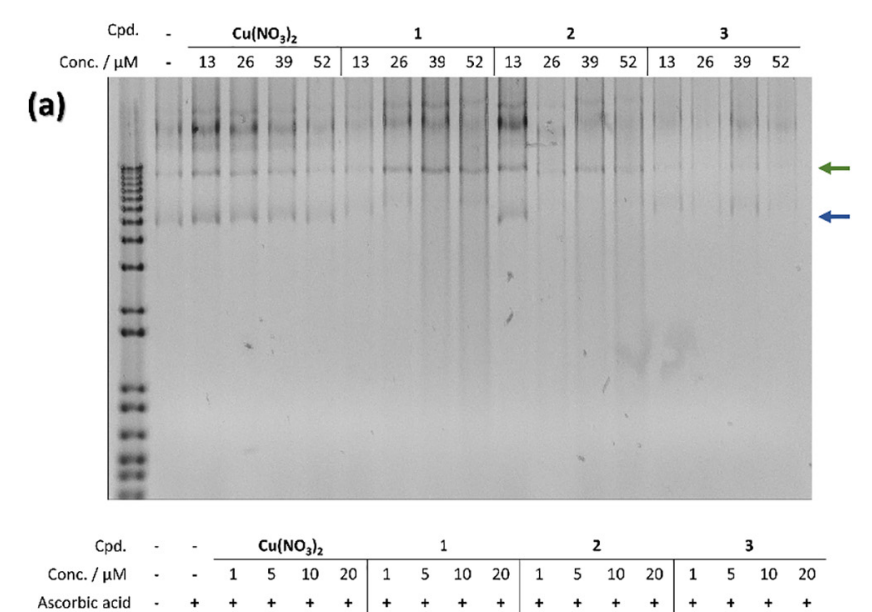

(b)

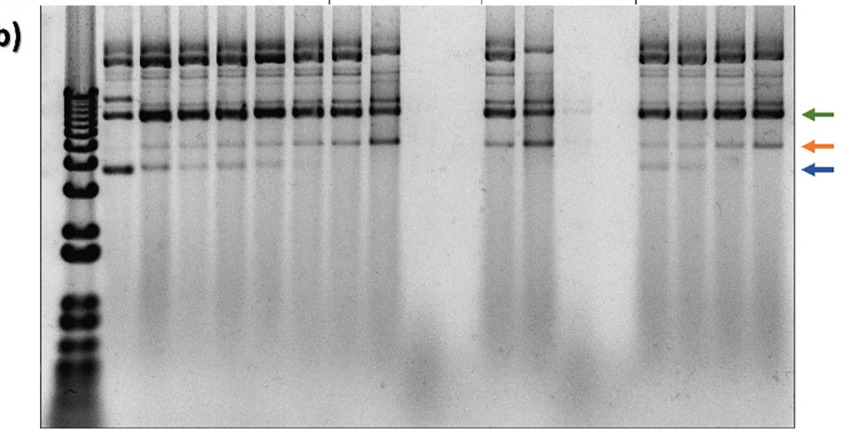

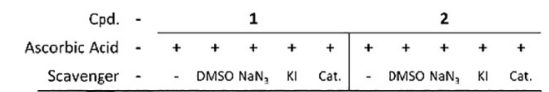

(c)

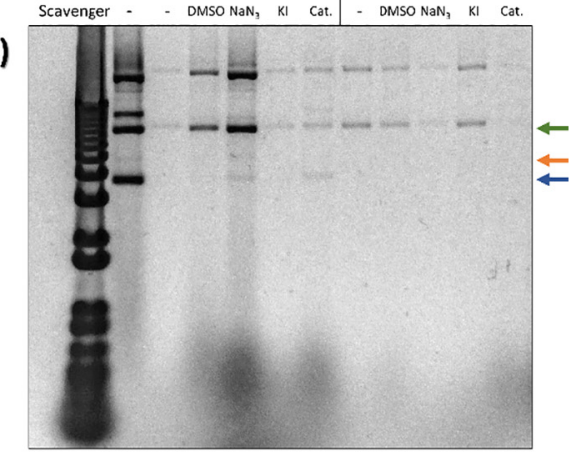

(d)

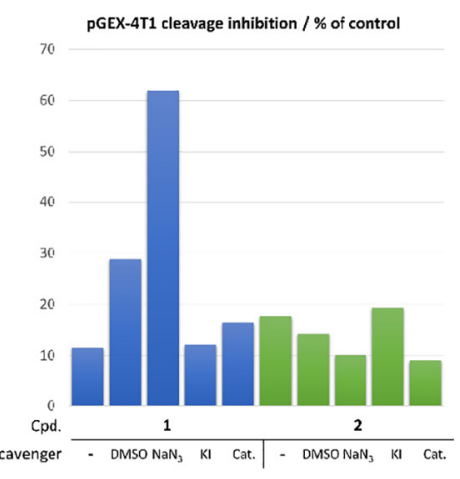

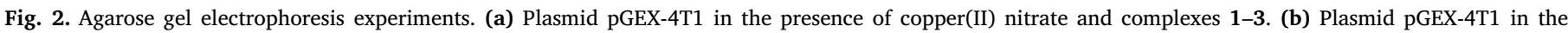

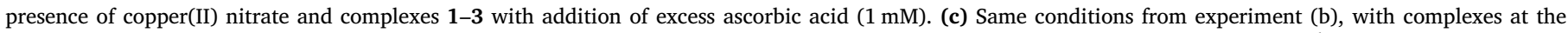

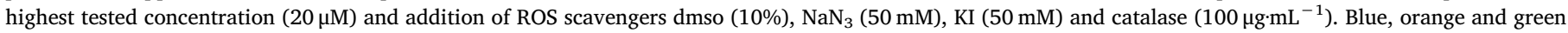

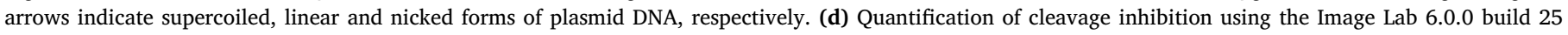
software (Bio-Rad laboratories), expressed as a percentage of the adjusted total lane volume of the untreated control.

three complexes can be characterized as a long and weak bond and the structures can be considered distorted 6-coordinate. These distorted structures and long axial bond lengths are the result of the Jahn-Teller effect, operating on the $\mathrm{d}^{9}$ electronic configuration of copper(II) and also of the narrow bite angles of the sulfonamides [38] (close to $60^{\circ}$, see Table 2), as observed for other complexes containing similar ligands. Beloso et al. reported crystal structures of similar complexes in which axial $\mathrm{Cu}-\mathrm{N}$ interactions were of the order of $2.5 \AA$ [39].

The copper(II) complex with sulfadimethoxine and ammonia molecules instead of a $\left(\mathrm{N}^{\wedge} \mathrm{N}\right)$ ligand, previously reported in the literature, was clearly a 5-coordinate complex, since the sixth theoretical axial $\mathrm{Cu}-\mathrm{N}$ "bond" is longer than $3.0 \AA$ [24, 40]. The copper complexes with benzothiazole-derived sulfonamides showed a similar coordination geometry to the complexes of this work, but the axial bond lengths longer than $2.8 \AA$ were not considered effective bonds by the authors [10].

A search for similar coordination spheres as of the title compounds was performed on the CSD [30] in order to validate the presence of such large bond lengths (searching parameters: six-coordinate copper(II) with one 5-membered chelate ring and two 4-membered rings; any donor atoms; connection of the donor chelates by $\mathrm{C}$ atoms; any bond order for the chelate rings), with 65 consistent hits. The results showed that carboxylate ligands are more commonly found as four-membered chelate rings with copper(II) and the average axial bond length was 2.54 (9) $\AA$, which is in agreement with the values observed for the structures of 1,2 and 3.

The equatorial bonds of the three complexes are on average of length $2.0 \AA$. This is consistent with bond lengths of copper(II)-sulfonamide- $\left(\mathrm{N}^{\wedge} \mathrm{N}\right)$ in ternary complexes reported in the literature [24, 39-41]. The copper(II)- $\mathrm{N}_{\text {phen }}$ values observed for complexes $\mathbf{1}$ and $\mathbf{2}$ are within the range of short lengths for such bonds $(<2.05 \AA$ ) [42]. The
Cu1-N7 (1.969 (3) $\AA$ ) of complex 1 is also at the lower limit of bond lengths found in the literature (2.00 (3) $\AA$ ) for copper(II)- $\mathrm{N}_{\text {pyrimidinyl }}$ bonds [42]. These factors are additional evidences of the presence of the Jahn-Teller effect in these complexes, leading to the compression of the equatorial bonds.

The supramolecular structures of $\mathbf{1}$ and $\mathbf{2}$ are organized by an extensive hydrogen bond network. The water molecules present in these structures are located at polar pockets within the crystal and form hydrogen bonds with the surrounding oxygen atoms from the sulfonamide groups, the $-\mathrm{NH}_{2}$ group of the aniline rings and the nitrogen atoms of the pyrimidinyl rings that are not coordinated to $\mathrm{Cu}(\mathrm{II})$. Even though the aniline ring bonded to the sulfur atom S1 of 1 seems be to stacked in an offset [43] way under the phen ligand (Fig. 1), the distance between the centroids of these rings is 4.969 (2) $\AA$, which is outside the range of what can be considered $\pi$-interactions [43]. On 2, however, intramolecular $\pi$-interactions are present on both copper sites, involving the phen and aniline rings of the sulfonamide. The centroid-centroid distance of this $\pi$-interaction for the structure of the first copper site $\mathrm{Cu} 1(C g 1 \cdots C g 2)$ is $3.573(2) \AA$, while for the second copper site $\mathrm{Cu} 2$ $(C g 3 \cdots C g 4)$ it is longer, 3.660 (2) ^ (Fig. S4).

The absence of water molecules on the crystal structure of $\mathbf{3}$ does not interfere with hydrogen bonding being the major contributor to crystal packing. The $-\mathrm{NH}_{2}$ groups present in this structure act as hydrogen-bond donors, while the oxygen atoms of the sulfonamide groups and the nitrogen atom of the pyrimidinyl ring, which is not involved in coordination, act as acceptors. The bpy ligand of compound 3 is not involved in $\pi$-interactions, but intramolecular offset $\pi$-stacking can be observed between one aniline ring and the pyrimidinyl ring of the other sulfonamide (Cg5‥Cg6), with distance of 3.741 (1) $\AA$ (Fig. S5). 


\subsection{Nuclease activity and interaction with models for DNA}

\subsubsection{Nuclease properties evaluated by agarose gel electrophoresis}

Copper(II) compounds have interesting nuclease properties that may be explored for the development of new classes of drugs. Sigman et al. introduced $\mathrm{Cu}$ complexes as potential nucleases using the model compound $\left[\mathrm{Cu}(\mathrm{I})(\text { phen })_{2}\right]^{+}[1]$. The active species, identified when ascorbic acid is used as reducing agent are the $\left[\mathrm{Cu}(\mathrm{I})(\mathrm{phen})_{2}\right]^{+}$complex, with a preference for $\mathrm{T}-3^{\prime}, 5^{\prime}$-A-steps, and the $[\mathrm{Cu}(\mathrm{I})(\mathrm{phen})]^{+}$ complex, which has a preference for CCGG sequences [44, 45]. These compounds may induce the formation of ROS in the medium, which then damage nucleic acids.

In order to evaluate the nuclease properties of the title compounds, samples of the pGEX-4T1 plasmid DNA were incubated with the compounds in three distinct experimental setups and then submitted to agarose gel electrophoresis. The first experiment was planned to evaluate the direct effect of the compounds on the structure of the plasmid pGEX-4T1. The plasmid was incubated with copper(II) nitrate and compounds 1-3 at 13, 26, 39 and $52 \mu \mathrm{M}$ and the results are presented in Fig. 2(a). In the tested conditions, copper(II) nitrate and compound 3 did not significantly alter the supercoiled and open circular populations of the plasmid in any of the tested concentrations, thus indicating no significant interaction or cleavage. Compounds 1 and 2, however, induced some DNA cleavage from $26 \mu \mathrm{M}$, since the supercoiled band became faded out. At 39 and $52 \mu \mathrm{M}$, a smearing of the lanes can be observed, which indicates that the compounds themselves can act as nucleases even in the absence of a reducing agent.

A second electrophoresis experiment was carried out in the presence of ascorbic acid, a reducing agent commonly used for the evaluation of nuclease properties of copper complexes via oxidative mechanisms. The results are shown in Fig. 2(b). A control lane, containing the pGEX4T1plasmid and ascorbic acid demonstrated that the reducing/oxidizing agent has some linearizing effect on plasmid (indicted by the orange arrow). Copper(II) nitrate induced some cleavage, especially at $20 \mu \mathrm{M}$, but even at this concentration the band of the supercoiled form can still be seen (blue arrow). Compound 3 presented a similar behavior, but at $10 \mu \mathrm{M}$ the band of the supercoiled form is no longer observable, thus showing a greater cleavage effect (probably dependent on the $\mathrm{Cu}(\mathrm{II})$-catalyzed ROS formation) than copper(II) nitrate. Compounds 1 and 2, however, presented a remarkable nuclease activity. Even at concentrations as low as $1 \mu \mathrm{M}$, no supercoiled band can be seen. At $10 \mu \mathrm{M}$, degradation of the plasmid occurs and only fragments of low molar mass are observed at the bottom-end of the gel. This observation highlights the effect of the $\left(\mathrm{N}^{\wedge} \mathrm{N}\right)$-bidentate ligand on the cleavage presented by compounds 1-3. The phen-containing compounds 1 and 2 demonstrated a much more prominent nuclease activity than the bpycontaining 3.

The nuclease activity of the model $\left[\mathrm{Cu}(\text { phen })_{2}\right]^{2+}$ compound was recently evaluated in the presence of the pBR322 plasmid [46]. Complete plasmid cleavage was observed only with treatment at $20 \mu \mathrm{M}$ and in the presence of ascorbate. Contrastingly, the compound $\mathrm{Cu}(o-$ phtalate)(phen)] also completely cleaved supercoiled pUC19 DNA at the concentration of $5 \mu \mathrm{M}$ in the presence of ascorbic acid [47]. Mixedligand copper(II)-sulfonamide-bpy complexes were shown to induce the linearization of supercoiled pUC18 in the presence of excess ascorbate, but complete cleavage was not achieved in any of the tested concentrations (maximum of $24 \mu \mathrm{M}$ complexes) [10].

Finally, a third experiment was set up to evaluate the nuclease mechanism of compounds $\mathbf{1}$ and $\mathbf{2}$, which led to complete degradation of the plasmid in the second experiment. The pGEX-4T1 plasmid was incubated with $\mathbf{1}$ and $\mathbf{2}$ in presence of ascorbic acid but also in the presence of ROS scavengers (Fig. 2(c) and (d)). The dmso (10\%) is a scavenger for $\cdot \mathrm{OH}, \mathrm{NaN}_{3}(50 \mathrm{mM})$ for singlet oxygen and $\mathrm{KI}(50 \mathrm{mM})$ and catalase $\left(100 \mu \mathrm{g} \cdot \mathrm{mL}^{-1}\right)$ for $\mathrm{H}_{2} \mathrm{O}_{2}[10,31,32]$. The complexes were evaluated at the highest concentration $(20 \mu \mathrm{M})$ from the experiment of cleavage in the presence of ascorbic acid presented in Fig. 2(b). For compound 1, plasmid cleavage was partially inhibited by dmso and $\mathrm{NaN}_{3}$, indicating that both $\mathrm{OH}$ and singlet oxygen species are involved in its nuclease activity mechanism. Quantification of this inhibition of cleavage is presented in Fig. 2(d). Interestingly, compound 2 differs from $\mathbf{1}$ as none of the ROS scavengers had a significant effect on the inhibition of DNA cleavage. This indicates that the nuclease mechanism of compound $\mathbf{2}$ is distinct from 1 . [ $\left.\mathrm{Cu}(\mathrm{I})(\text { phen })_{2}\right]^{+}$exerts its nuclease effects mediated mainly by $\cdot \mathrm{OH}$ and $\mathrm{O}_{2}^{-}$species, whereas singlet oxygen has a negligible contribution [46, 48]. McGivern et al. recently reviewed copper complexes as metallonucleases and verified that $\cdot \mathrm{OH}$ and singlet oxygen are the most common ROS involved in the cleavage mechanism, in agreement to what was observed for compound $\mathbf{1}$. The $\mathrm{O}_{2}{ }^{-}$species is much less common, but was also reported as a possibility [7]. These results demonstrated that, although compounds 1 and 2 share the copper-phen moiety, differences on the nuclease activity arise based on the sulfonamide as well.

\subsubsection{Molecular mechanism of the nuclease activity - Investigating the} reaction with ascorbic acid

To evaluate possible copper species responsible for the nuclease properties of the complexes, we acquired mass spectra of 1-3 in the presence of ascorbic acid at time zero (immediately after mixing) and after $24 \mathrm{~h}$ of reaction. The obtained mass spectra for compound $\mathbf{1}$, which is representative of the behavior of all compounds, are shown in Fig. 3, while the spectra of $\mathbf{2}$ and $\mathbf{3}$ are given in Figs. S6 and S7 of Supporting Information.

The mass spectrum of compound $\mathbf{1}$ in the absence of ascorbic acid (Fig. 3(a)) shows many species and indicates that some ligand recombination takes place under the experimental conditions used for data acquisition. Formic acid, which was added for the protonation of the neutral complexes may also protonate the sulfonamide and facilitate its dissociation. Furthermore, though electrospray is considered a "soft" method of ionization, copper(II) compounds are commonly reduced during this process [49]. Reduction of the title compounds facilitates dissociation due to different ligand affinities of copper(I) and copper(II).

Despite all these conditions, peaks corresponding to the proposed formulas of $\left[\mathrm{Cu}(\mathrm{II})\left(\mathrm{sulfa}^{-}\right)_{2}\left(\mathrm{~N}^{\wedge} \mathrm{N}\right)+\mathrm{H}^{+} \quad\left(\mathrm{N}^{\wedge} \mathrm{N}=\right.\right.$ bpy or phen; sulfa $^{-}=$deprotonated sulfameter or sulfadimethoxine) were observed for the three complexes. In solution, the compounds seem to maintain the original composition, as their electronic spectra in phosphate buffer (pH 7.4) do not change significantly after $24 \mathrm{~h}$ at $37^{\circ} \mathrm{C}$ (see Fig. S8).

The reaction of $\mathbf{1}$ with ascorbic acid leads to a spectrum that has [Cu (I)(phen) $\left.]_{2}\right]^{+}$as the base peak at $423.0056 \mathrm{~m} / z$, immediately after mixing, Fig. 3(b). Concomitantly, the peak corresponding to the complex 1 at $802.1082 \mathrm{~m} / \mathrm{z}$ disappears and a new peak at $623.0517 \mathrm{~m} / \mathrm{z}$ can be observed, see inserts of Fig. 3(b). This signal corresponds to the formation of $\left[\mathrm{Cu}(\mathrm{I})(\mathrm{smtrH})_{2}\right]^{+}$, where the sulfonamide ligands have been protonated (and are now neutral) and copper(II) has been reduced. However, after $24 \mathrm{~h}$ of reaction, oxidation by air seems to return the speciation to the one observed without the addition of ascorbic acid, with differences in relative intensities. $\left[\mathrm{Cu}(\mathrm{I})(\mathrm{sdmxH})\left(\mathrm{N}^{\wedge} \mathrm{N}\right)\right]^{+}$species are also observed in the mass spectra of 2 and 3 (553.0273 and $529.0434 \mathrm{~m} / \mathrm{z}$, respectively).

The reaction of compound $\mathbf{1}$ with ascorbic acid was further investigated by ${ }^{1} \mathrm{H}$ NMR, in dmso-d6, and the resulting spectra are given in Fig. S9. The spectrum acquired after addition of ascorbic acid showed an increased signal resolution and well-defined bands are observed, indicating partial reduction of copper(II). During $30 \mathrm{~min}$ of reaction, changes on the shape of signals assigned to the sulfonamide ligand were observed. These changes are probably associated with the reduction of copper and concomitant change of the coordination sphere, being in a good agreement with mass spectrometric experiments.

After approximately 20 days, single-crystals suitable for diffraction formed in the NMR tube where the reaction with ascorbic acid was performed. The determined structure showed polymeric $\{[\mathrm{Cu}(\mathrm{II})$ 


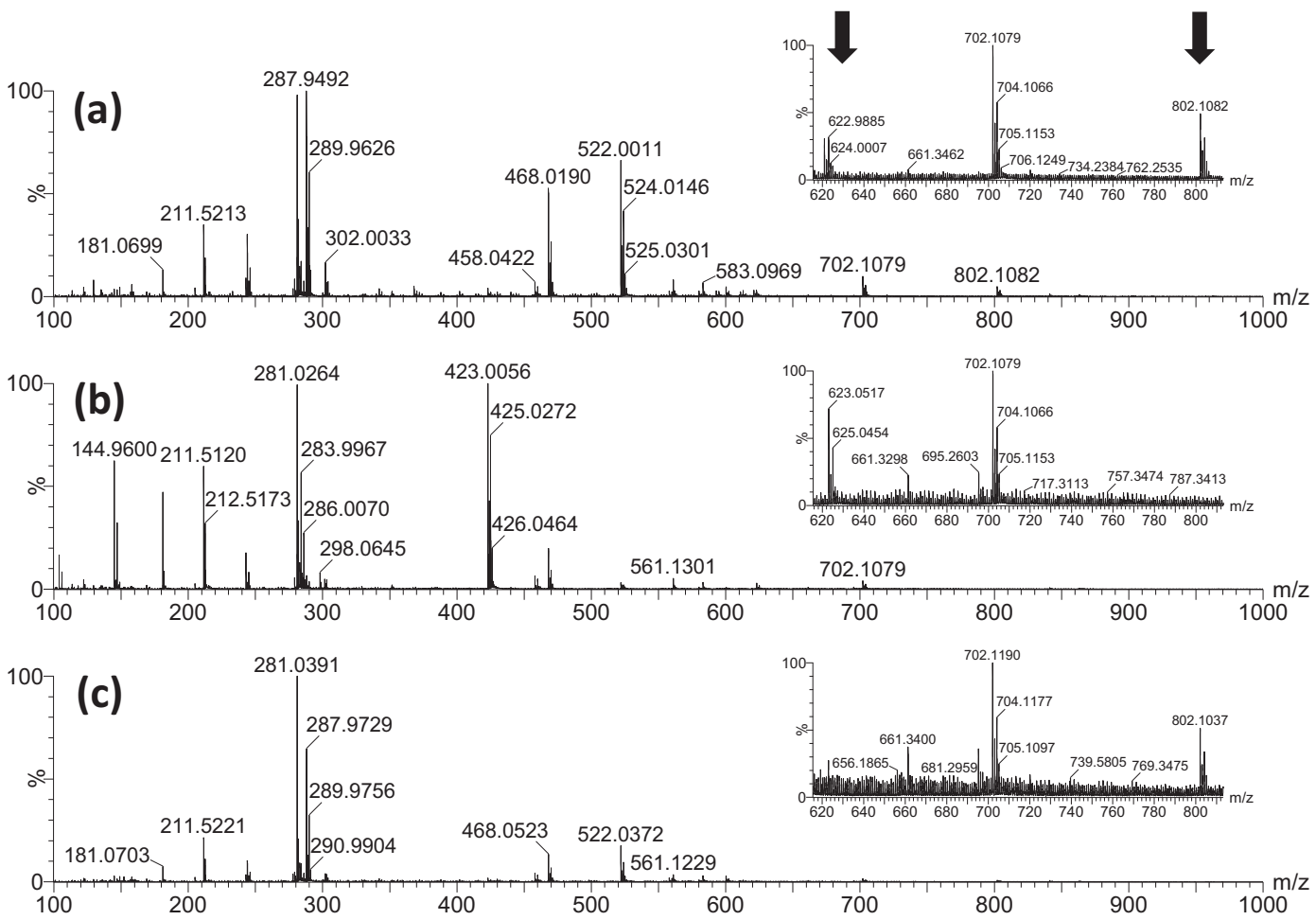

Fig. 3. Mass spectra of compound 1 (a) in the absence and (b) in the presence of ascorbic acid at $t=0$ and (c) $t=24 \mathrm{~h}$.

(oxalate)(phen)]-2dmso $\}_{\mathrm{n}}$ (see Figs. S10 and S11). Oxalate is the end product of oxidation of ascorbic acid and it has long been known that copper(II) catalyzes this reaction [50]. This crystal structure corroborates with the nuclease properties of the compounds observed in gel electrophoresis. Curiously, it does not present the $\left[\mathrm{Cu}(\mathrm{II})(\mathrm{phen})_{2}\right]^{2+}$ moiety, as observed in mass spectrometric results.

The results show that the copper(II) complexes may form [Cu(I) $\left.\left(\mathrm{N}^{\wedge} \mathrm{N}\right)_{2}\right]^{+},\left[\mathrm{Cu}(\mathrm{I})\left(\mathrm{N}^{\wedge} \mathrm{N}\right)(\text { sulfa })\right]^{+}$and $\left[\mathrm{Cu}(\mathrm{I})(\text { sulfa })_{2}\right]^{+}$intermediates in the presence of ascorbic acid, which are chemically relevant species for the nuclease properties observed in the gel electrophoresis experiments.

3.2.3. Probing the modes of DNA binding in the absence of reducing agents 3.2.3.1. Competitive binding. Since the nuclease activity depends not only on the redox properties of copper, but also on the binding directed by the ligands, we designed two competitive binding experiments to assess whether the compounds 1-3 have intercalating or groove binding capabilities. Ethidium bromide (EB) interacts with DNA by forming intercalated adducts. Molecules that are able to quench the fluorescence of DNA-bound EB usually do so by its displacement and are thus intercalators. Similarly, Hoechst 33,258 is a dye that binds to the minor groove of DNA and this interaction also gives rise to fluorescence. The quenching of fluorescence from these DNA-bound molecules could point to the mode and magnitude of interaction of the compounds with DNA. The Stern-Volmer treatment of the data from these fluorescence quenching experiments is presented in Fig. S12, while Table 3 lists the values of $\mathrm{K}_{\mathrm{SV}}$.

From Fig. S12 and Table 3, it is clear that the compounds interact with calf-thymus DNA and are able to displace both EB and Hoechst from DNA binding sites. For both dyes, the order of interaction was $\mathbf{1}>\mathbf{2}>\mathbf{3}$ and the complexes seem to be better groove-binders than intercalators. Phenanthroline seems to lead to a greater affinity of the complexes 1 and 2 for DNA when compared to bpy of compound 3. However, the effect of the sulfonamide is remarkable on the binding affinity and it influences the preferred mode of interaction of the complexes with DNA. The sulfonamide smtrH of 1 seems to approximately double the magnitude of interaction with DNA when compared
Table 3

$\mathrm{K}_{\mathrm{SV}}$ values for the competitive binding of compounds 1-3 with EB-DNA and Hoechst-DNA systems.

\begin{tabular}{lll}
\hline Compound & $\mathrm{K}_{\mathrm{SV}}\left(10^{3} \mathrm{M}^{-1}\right)$ EB-DNA & $\mathrm{K}_{\mathrm{SV}}\left(10^{3} \mathrm{M}^{-1}\right)$ Hoechst-DNA \\
\hline $\mathbf{1}$ & $5.88 \pm 0.03$ & $18.92 \pm 0.29$ \\
$\mathbf{2}$ & $3.60 \pm 0.08$ & $7.76 \pm 0.11$ \\
$\mathbf{3}$ & $1.96 \pm 0.07$ & $2.60 \pm 0.04$ \\
\hline
\end{tabular}

to 2 . Moreover, $\mathbf{1}$ is approximately three times more groove binder than intercalator, whereas $\mathbf{2}$ and $\mathbf{3}$ are only twice more groove binders. These observations indicate that the magnitude and mode of binding of the complexes to DNA prior to reduction are as important as the nature of the ROS and copper species involved in the mechanism to determine the nuclease properties observed in the cleavage of plasmid DNA.

3.2.3.2. Secondary structure modifications. Circular dichroism (CD) is a useful technique for evaluating DNA secondary structure and the changes in its conformation after interaction with drugs. The $C D$ spectrum of DNA in B form exhibits a negative band at $245 \mathrm{~nm}$, related to right-handed helicity, and a positive band at $275 \mathrm{~nm}$, related to base stacking [51]. The CD spectra of the interaction of the copper(II) complexes with calf-thymus DNA are shown in Fig. S13.

Compounds 1 and 2 induced an increase on the intensity of the positive band (at $275 \mathrm{~nm}$ ) of CT-DNA, which is a typical phenomenon observed for intercalating agents [52, 53]. These two copper complexes have a phen ligand, which could be responsible for the partial intercalation of the molecules between the base-pairs of DNA and this is consistent with fluorescence data. However, it is known that the presence of the phenanthroline ring does not necessarily result in exclusively intercalating agents. Tris-(phen) metal complexes, for example, may act as minor groove binders and as partial intercalators in the major groove [54]. Compound 3 did not induce any significant changes on the spectrum of DNA, thus indicating that no intercalation occurs, making exclusive groove binding a possible mode of interaction of this compound to DNA, since groove binders do not significantly 
Table 4

Glide Docking scores for the $\mathrm{Cu}(\mathrm{II})$ compounds binding the two selected model DNA molecules (Dickerson-Drew Dodecamer and model DNA containing a gap caused by an intercalator molecule).

\begin{tabular}{lll}
\hline \multirow{2}{*}{ Compound } & \multicolumn{2}{l}{ Docking score } \\
\cline { 2 - 3 } & DDD DNA (4C64) & Gap DNA (4LY2) \\
\hline 1 & -2.693 & -4.403 \\
$2_{\mathrm{Cu} 1}$ & -6.309 & -8.113 \\
$2_{\mathrm{Cu} 2}$ & -3.824 & -6.723 \\
3 & -5.652 & -6.647 \\
\hline
\end{tabular}

alter the profile of its CD spectra [53].

3.2.3.3. Molecular docking. Since intercalation and groove binding are important factors governing the nuclease activity of copper compounds, molecular docking calculations were performed to model the interaction of compounds 1-3 with DNA. The two different molecular entities observed in the crystal structure of compound $\mathbf{2}\left(\mathbf{2}_{\mathrm{Cu} 1}\right.$ and $\mathbf{2}_{\mathrm{Cu} 2}$, see Fig. 1) were independently evaluated.

The fluorescence quenching assay was done using CT-DNA. To get insights about binding preferences to specific DNA sequences, two well established short DNA sequences were selected for the docking calculations, the Dickerson-Drew Dodecamer (DDD DNA) and a short sequence crystalized with a metal complex intercalator, here referred to as Gap DNA (see the Experimental Section for details). The Glide Docking scores are given in Table 4, while Fig. 4 presents the best poses found for the compounds docked in the Dickerson-Drew Dodecamer DNA.

The docking calculations indicate that compounds $\mathbf{1 - 3}$ act as groove-binders when DDD DNA is used as a receptor. This observation agrees with the findings obtained using density functional theory, molecular docking and molecular dynamics calculations for copperphen complexes interacting with a DNA fragment [6]. Compound 1 binds to the major groove, with one of the sulfonamide ligands facing directly towards the major groove. The second sulfonamide ligand and phen appear facing outwards. The compound seems to favor the A-T pairs, located in the central region of the model DDD DNA molecule, but one of the sulfonamide ligands is located nearby a C-G pair. Compounds $\mathbf{2}_{\mathrm{Cu} 1}, \mathbf{2}_{\mathrm{Cu} 2}$ and $\mathbf{3}$, on the other hand, appeared as minor groove binders, and position themselves in the neighborhood of two adjacent A-T pairs. Compound $\mathbf{2}_{\mathrm{Cu} 1}$ inserts one of the sulfonamide ligands in the minor groove, while the other one surrounds the phosphate backbone. The phenanthroline ligand points outwards. Compound $\mathbf{2}_{\mathrm{Cu} 2}$, although located in the same region, does not have a group inserted into the minor groove. The aniline moieties of both sulfonamides and one of the pyrimidinyl groups surround the phosphate backbone, while the remaining pyrimidinyl moiety points outwards. The phen ligand appears in close proximity to the phosphate backbone. Compound $\mathbf{3}$ has one of the aniline groups inserted directly into the minor groove, with the other aniline and the bpy ligand in close proximity to the phosphate backbone. Both pyrimidinyl groups face outwards in relation to the minor groove.

To properly reproduce intercalation, a DNA structure containing a
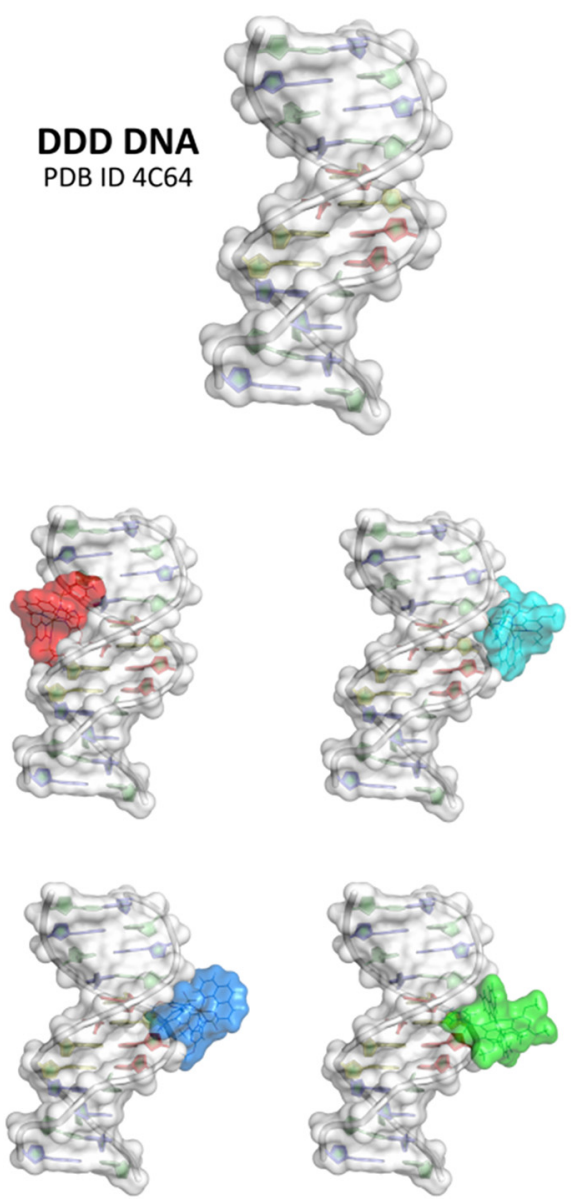
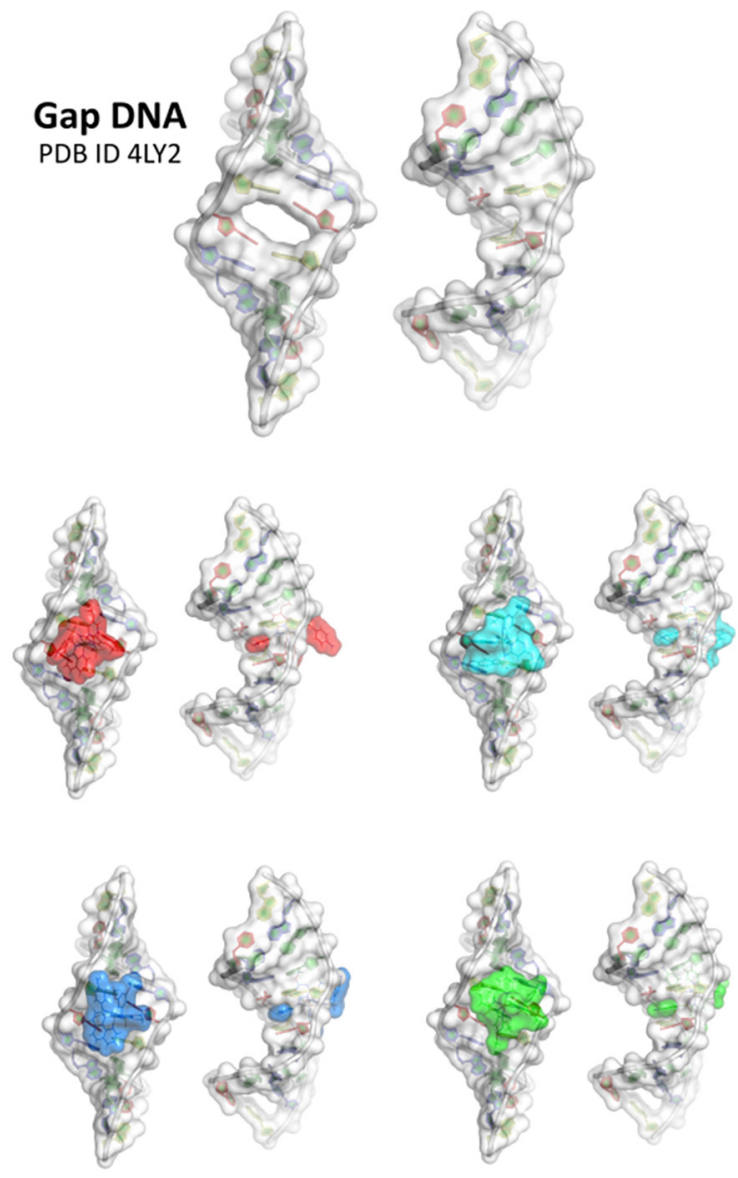

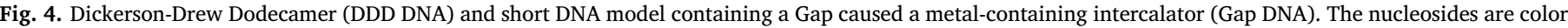

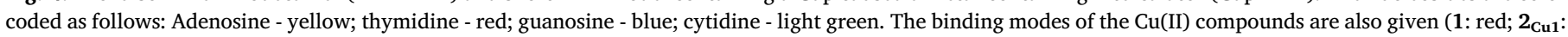

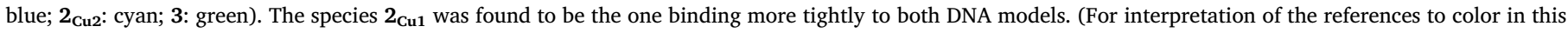
figure legend, the reader is referred to the web version of this article.) 
gap caused by an actual intercalator can be used, as suggested by Ricci et al. [34]. For this purpose, the DNA structure 4LY2 was selected as a receptor and compared to the typical DDD B-DNA (4C64). Although the structure of 4LY2 has 3 "gaps" (a central one located between two AT pairs and two terminal gaps, between an AT and a CG pair), the docked $\mathrm{Cu}$ (II) compounds were all found to bind to the central gap, showing some selectivity towards the AT pairs. The docking scores for $4 \mathrm{LY} 2$ were always lower than the corresponding scores found for the same compound binding to DDD DNA. Interestingly, despite the presence of bpy/phen in the structure compounds $\mathbf{1 - 3}$, docking calculations indicated that the sulfonamide ligand was the most likely intercalating group for the gap found in the structure of $4 \mathrm{LY} 2$.

The structure $\mathbf{2}_{\mathrm{Cu}}$ has the best binding scores for both DNA models considered here, which is consistent with the nuclease activity observed by gel electrophoresis. Compound 3 has comparatively high affinity for both DNA models as well, which suggests that the lack of nuclease activity is not related to the DNA binding itself. We can suggest that the electronic properties of the bpy-bound $\mathrm{Cu}(\mathrm{II})$ are therefore the most likely cause for the lack of nuclease activity observed for compound $\mathbf{3}$.

\subsection{Growth inhibition assays}

\subsubsection{Antimycobacterial activities}

Copper(II) complexes have recently gained attention for the development of metallodrugs for the treatment of tuberculosis [18, 19]. Increasing intracellular bactericidal copper content in $M$. tuberculosis via compounds that cross the mycobacterial outer membrane barrier is a promising strategy for the development of novel drugs [18]. The copper (II) complexes synthesized in this work were tested over the ATCC $M$. tuberculosis H37Rv strain and the $\mathrm{MIC}_{90}$ values are given in Table 5.

The three copper(II) complexes were found to be much more active over M. tuberculosis (on the micromolar range,) than the starting materials (copper salt, sulfonamides and $\left(\mathrm{N}^{\wedge} \mathrm{N}\right)$-bidentate ligand). The phen-containing complexes $\mathbf{1}$ and $\mathbf{2}$ were three times more active than compound $\mathbf{3}$. This is consistent with the greater nuclease activity of $\mathbf{1}$ and 2, as observed by agarose gel electrophoresis experiments. Even though the complexes were less active than the first and second line antibiotics for tuberculosis (rifampicin and ciprofloxacin, respectively), the development of antimicrobial resistance is a major cause of concern and new classes of drugs are required. The $\mathrm{MIC}_{90}$ values of the three complexes are similar to those found for the copper(II) complexes Casiopeínas $^{\circledast}$ (between 6.9 and $14.0 \mu \mathrm{M}$ ) against the same $M$. tuberculosis strain [55]. When compared to other copper- $\left(\mathrm{N}^{\wedge} \mathrm{N}\right)$ complexes reported in the literature, compounds 1-3 were more active against $M$. tuberculosis than the complexes containing 3-hydroxypicolinic acid and bpy $(>55 \mu \mathrm{M})$ or phen $(25 \mu \mathrm{M})$ [56]. The classical antibacterial sulfonamides usually do not present remarkable activities over $M$. tuberculosis, although sulfamethoxazole-trimethoprim seems to exert a significant activity against several clinical isolates [57]. The sulfonamides used in this work presented only moderate activities over the

Table 5

Antimycobacterial activity of the $\mathrm{Cu}(\mathrm{II})$ complexes and starting materials over $M$. tuberculosis H37Rv (ATCC 27294).

\begin{tabular}{lc}
\hline Compound & $\mathrm{MIC}_{90}(\mu \mathrm{M})$ \\
\hline Rifampicin & $<0.1$ \\
Ciprofloxacin & $0.9 \pm 0.1$ \\
$\mathrm{Cu}\left(\mathrm{NO}_{3}\right)_{2} \cdot 3 \mathrm{H}_{2} \mathrm{O}$ & $63.0 \pm 15.9$ \\
$\mathrm{smtrH}$ & $88.8 \pm 0.6$ \\
sdmxH & $46.1 \pm 8.3$ \\
bpy & $>160$ \\
phen & $28.2 \pm 14.0$ \\
1 & $6.2 \pm 0.8$ \\
2 & $7.8 \pm 1.2$ \\
3 & $21.4 \pm 6.0$ \\
\end{tabular}

tested strain, but the coordination to copper(II) complexes containing $\left(\mathrm{N}^{\wedge} \mathrm{N}\right)$-bidentate ligands resulted in molecules with prominent antimycobacterial activities.

\subsubsection{Antiproliferative activities}

The antiproliferative activities of compounds 1-3 were assayed in vitro following the protocol of the NCI-60 human tumor cell line anticancer drug screen against a panel of 10 cell lines [58]. Although three dose-response parameters can be calculated from the data (GI50, TGI and LC50), the total growth inhibition parameter (TGI) allowed a more straightforward comparison of the activity of the compounds and the values are given in Table 6.

The values from Table 6 demonstrate that the three copper(II) complexes have a much more pronounced activity profile when compared to the starting materials (copper(II) salt and free ligands). Among the ligands, only phen was active (but at high micromolar concentrations). Compounds $\mathbf{1}$ and $\mathbf{2}$ showed low micromolar cytostatic effects over glioma, melanoma, lung, ovarian and colon cancer cell lines. However, 2 showed higher selectivity, as it was less active over the nontumor human line of immortal keratinocytes $(46 \mu \mathrm{M})$, when compared to $1(14 \mu \mathrm{M})$. This indicates that the sulfonamide modulates the activity profile of the complexes, since sulfadimethoxine ( $\mathrm{sdmxH}$ ) present in compound $\mathbf{2}$ improved the selectivity of the compound towards cancer cells. The values are also consistent with what was observed in DNA cleavage experiments. Compound $\mathbf{3}$ showed the lowest nuclease activity, which translated into the lowest growth inhibition potency (largest average TGI values observed across the cell panel evaluated here). Compounds $\mathbf{1}$ and $\mathbf{2}$, on the other hand, presented promising activity over the cell lines studied here.

For comparison, Slator et al. performed a full NCI-60 experiment on the compound [Cu(o-phtalate)(phen)] [47]. The authors verified that the compound showed superoxide-mediated activity over almost all cells of the panel, excluding leukemia, with TGI values ranging from 0.5 to $7 \mu \mathrm{M}$, which agree with the values observed for our compounds over some cell lines (specially melanoma, glioma, ovarian and colon). While the nature of the ROS generated by compound $\mathbf{2}$ was not identified here and could be superoxide, as described for [Cu(o-phtalate)(phen)], compound 1 showed nuclease activity mediated mainly by singlet oxygen. Another example is the complex [Cu(2,2-dimethylglycine) (phen) $\left(\mathrm{H}_{2} \mathrm{O}\right) \mathrm{NO}_{3}$, which induced lethality over a variety of cell lines of NCI-60 at $10 \mu \mathrm{M}$ [59].

\section{Conclusions}

Three novel copper(II) complexes containing sulfonamides and $\left(\mathrm{N}^{\wedge} \mathrm{N}\right)$-bidentate ligands were synthesized in this work, aiming to expand on and fine-tune the reactivity of the class of compounds known as copper(II)-based metallonucleases. Compounds $\mathbf{1}$ and $\mathbf{2}$ were able to linearize the supercoiled pGEX-4T1 plasmid in the absence of reducing agents, indicating the importance of the phen ligand. Addition of ascorbic acid resulted in complete cleavage of DNA by 1 and 2 at $10 \mu \mathrm{M}$, with different ROS species involved in the mechanism. When probing the mode of interaction of the complexes with DNA in the absence of ascorbic acid, it was found that the magnitude and preferred mode of binding are dependent on the nature of both $\mathrm{N}^{\wedge} \mathrm{N}$ ligand and sulfonamide. Therefore, the different binding of 1-3 to DNA prior to reduction is also a key parameter to determine their distinct nuclease properties in the cleavage of plasmid DNA. The potent nuclease activity and the distinct effect of the sulfonamide of compounds $\mathbf{1}$ and $\mathbf{2}$ correlated well with their antiproliferative and anti-M. tuberculosis profiles. The results presented here demonstrated the potential for further development of copper(II)-sulfonamide-( $\left.\mathrm{N}^{\wedge} \mathrm{N}\right)$ complexes as tunable artificial nucleases and as novel multipurpose metallodrugs. 
Table 6

Total growth inhibition $(\mu \mathrm{M})$ profile of the copper(II) complexes, compared to the starting reagents and to doxorubicin (doxo).

\begin{tabular}{|c|c|c|c|c|c|c|c|c|c|c|}
\hline \multirow[t]{2}{*}{ Compound } & \multicolumn{10}{|c|}{ Cell lines } \\
\hline & U251 & UACC-62 & MCF-7 & NCI-ADR/RES & $786-0$ & NCI-H460 & OVCAR-3 & HT29 & K562 & HaCat \\
\hline Doxo & 0.1 & 1.4 & $\mathrm{a}$ & $\mathrm{a}$ & 0.4 & a & 26.5 & a & 11.6 & a \\
\hline $\mathrm{Cu}\left(\mathrm{NO}_{3}\right)_{2}$ & a & a & a & a & a & $\mathrm{a}$ & a & a & 172.6 & a \\
\hline smtrH & a & a & a & a & a & $\mathrm{a}$ & a & a & a & a \\
\hline sdmxH & a & $\mathrm{a}$ & a & a & a & a & a & a & a & $\mathrm{a}$ \\
\hline Bpy & a & a & a & a & a & a & a & a & 178.0 & a \\
\hline Phen & 192.2 & 51.5 & 229.5 & 784.0 & 38.3 & 255.8 & 111.0 & 134.2 & 26.2 & a \\
\hline 1 & 1.4 & 5.1 & 15.4 & a & a & 7.9 & 3.3 & 6.3 & 35.4 & 14.0 \\
\hline $2^{\mathrm{b}}$ & $<0.3$ & 7.8 & 46.4 & 111.0 & 47.9 & 7.1 & 4.7 & 4.9 & 32.5 & 46.1 \\
\hline 3 & 35.3 & 51.2 & 217.0 & a & a & 64.8 & 75.9 & 129.3 & a & a \\
\hline
\end{tabular}

Human tumor cell lines: glioma (U251); melanoma (UACC-62); breast (MCF-7); multidrug resistant ovarian (NCI-ADR/RES); renal (786-0); lung, non-small cells (NCI-H460); ovarian (OVCAR-3); colon (HT29); leukemia (K562); immortal keratinocyte, non-tumor human line (HaCat).

${ }^{\text {a }}$ Values greater than the highest tested concentration $(25 \mu \mathrm{g} / \mathrm{mL}$ for Doxo, $250 \mu \mathrm{g} / \mathrm{mL}$ for the other compounds. The maximum concentrations correspond to:

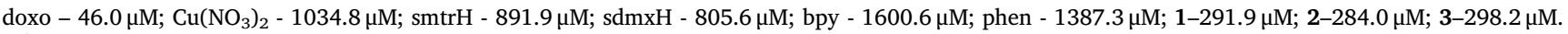

b Since the crystal structure of 2 consisted of two coordination isomers in the asymmetric unit (Fig. 1), only half of the molecular mass was used to calculate the TGI in $\mu$ M.

\section{Accession codes}

CCDC 1812150-1,812,153 contain the supplementary crystallographic data for this paper. These data can be obtained free of charge via www.ccdc.cam.ac.uk/data_request/cif, or by emailing data request@ccdc.cam.ac.uk, or by contacting The Cambridge Crystallographic Data Centre, 12 Union Road, Cambridge CB2 1EZ, UK; fax: + 441223336,033 .

\section{Notes}

The authors declare no competing financial interest.

\section{Acknowledgements}

This work was funded by the Brazilian Council of Technological and Scientific Development (CNPq, scholarship No. 140466/2014-2 to Raphael E. F. de Paiva; Grant No. 442123/2014-0 to Pedro P. Corbi); São Paulo Research Foundation (FAPESP, scholarship No. 2015/208823 to Douglas H. Nakahata; grant No. 2015/09833-0 to Wilton R. Lustri; grant No. 2015/25114-4 to Pedro P. Corbi). The authors are grateful to Prof. Dr. Marcos A. Ribeiro for fruitful discussions about X-ray crystallographic refinements.

\section{Appendix A. Supplementary data}

Supplementary data to this article can be found online at https:// doi.org/10.1016/j.jinorgbio.2018.07.011.

\section{References}

[1] D.S. Sigman, D.R. Graham, V. D'Aurora, A.M. Stern, Oxygen-dependent cleavage of DNA by the 1,10-phenanthroline cuprous complex. Inhibition of Escherichia coli DNA polymerase I, J. Biol. Chem. 254 (1979) 12269-12272.

[2] L.E. Marshall, D.R. Graham, K.A. Reich, D.S. Sigman, Cleavage of deoxyribonucleic acid by the 1,10-phenanthroline-cuprous complex. Hydrogen peroxide requirement and primary and secondary structure specificity, Biochemistry 20 (1981) 244-250.

[3] T.B. Thederahn, M.D. Kuwabara, T.A. Larsen, D.S. Sigman, Nuclease activity of 1,10-phenanthroline-copper: kinetic mechanism, J. Am. Chem. Soc. 111 (1989) 4941-4946, https://doi.org/10.1021/ja00195a057.

[4] D.S. Sigman, A. Mazumder, D.M. Perrin, Chemical nucleases, Chem. Rev. 93 (1993) 2295-2316, https://doi.org/10.1021/cr00022a011.

[5] C. Wende, C. Lüdtke, N. Kulak, Copper complexes of N-donor ligands as artificial nucleases, Eur. J. Inorg. Chem. (2014) 2597-2612, https://doi.org/10.1002/ejic. 201400032.

[6] A. Robertazzi, A.V. Vargiu, A. Magistrato, P. Ruggerone, P. Carloni, P. de Hoog, J. Reedijk, Copper-1,10-phenanthroline complexes binding to DNA: structural predictions from molecular simulations, J. Phys. Chem. B 113 (2009) 10881-10890, https://doi.org/10.1021/jp901210g.
[7] T.J.P. McGivern, S. Afsharpour, C.J. Marmion, Copper complexes as artificial DNA metallonucleases: from Sigman's reagent to next generation anti-cancer agent? Inorg. Chim. Acta 472 (2018) 12-39, https://doi.org/10.1016/j.ica.2017.08.043.

[8] D.S. Sigman, Nuclease activity of 1,10-phenanthroline-copper ion, Acc. Chem. Res. 19 (1986) 180-186, https://doi.org/10.1021/ar00126a004.

[9] Z.-S. Yang, Y.-L. Wang, G.-C. Zhao, The interaction of copper-bipyridyl complex with DNA and cleavage to DNA, Anal. Sci. 20 (2004) 1127-1130.

[10] M. González-Álvarez, A. Pascual-Álvarez, L. del Castillo Agudo, A. Castiñeiras, M. Liu-González, J. Borrás, G. Alzuet-Piña, Mixed-ligand copper(ii)-sulfonamide complexes: effect of the sulfonamide derivative on DNA binding, DNA cleavage, genotoxicity and anticancer activity, Dalton Trans. 42 (2013) 10244, https://doi. org/10.1039/c3dt50416f.

[11] G. Pratviel, J. Bernadou, B. Meunier, Carbon-hydrogen bonds of DNA SUGAR UNITS AS TARGETS FOR CHEMICAL NUCLEASES AND DRUGS, Angew. Chem. Int. Ed. Eng. 34 (1995) 746-769, https://doi.org/10.1002/anie.199507461.

[12] M.E. Bravo-Gómez, J.C. García-Ramos, I. Gracia-Mora, L. Ruiz-Azuara, Antiproliferative activity and QSAR study of copper(II) mixed chelate $[\mathrm{Cu}(\mathrm{N}-\mathrm{N})$ (acetylacetonato) $] \mathrm{NO}_{3}$ and $\left[\mathrm{Cu}(\mathrm{N}-\mathrm{N})(\right.$ glycinato) $] \mathrm{NO}_{3}$ complexes, (Casiopeínas ${ }^{\circledR}$ ), J. Inorg. Biochem. 103 (2009) 299-309, https://doi.org/10.1016/j.jinorgbio.2008. 10.006 .

[13] J. Serment-Guerrero, M.E. Bravo-Gomez, E. Lara-Rivera, L. Ruiz-Azuara, Genotoxic assessment of the copper chelated compounds Casiopeinas: clues about their mechanisms of action, J. Inorg. Biochem. 166 (2017) 68-75, https://doi.org/10.1016/ j.jinorgbio.2016.11.007.

[14] C.T. Supuran, A. Casini, A. Scozzafava, Protease inhibitors of the sulfonamide type: anticancer, antiinflammatory, and antiviral agents, Med. Res. Rev. 23 (2003) 535-558, https://doi.org/10.1002/med.10047.

[15] Y. Wu, S. Yu, F. Yu, N. Yan, L. Qu, H. Zhang, Chemiluminescence enzyme immunoassay for the determination of sulfamethoxydiazine, Spectrochim. Acta A Mol. Biomol. Spectrosc. 81 (2011) 544-547, https://doi.org/10.1016/j.saa.2011.06.047.

[16] V. Law, C. Knox, Y. Djoumbou, T. Jewison, A.C. Guo, Y. Liu, A. Maclejewski, D. Arndt, M. Wilson, V. Neveu, A. Tang, G. Gabriel, C. Ly, S. Adamjee, Z.T. Dame, B. Han, Y. Zhou, D.S. Wishart, DrugBank 4.0: shedding new light on drug metabolism, Nucleic Acids Res. 42 (2014) 1-7, https://doi.org/10.1093/nar/gkt1068.

[17] World Health Organization, Global Tuberculosis Report, (2016).

[18] A. Speer, T.B. Shrestha, S.H. Bossmann, R.J. Basaraba, G.J. Harber, S.M. Michalek, M. Niederweis, O. Kutsch, F. Wolschendorf, Copper-boosting compounds: a novel concept for antimycobacterial drug discovery, Antimicrob. Agents Chemother. 57 (2013) 1089-1091, https://doi.org/10.1128/AAC.01781-12.

[19] M. Wehbe, A.W.Y. Leung, M.J. Abrams, C. Orvig, M.B. Bally, A perspective - can copper complexes be developed as a novel class of therapeutics? Dalton Trans. 22 (2017) 3860-3875, https://doi.org/10.1039/C7DT01955F.

[20] World Health Organization, Cancer, http://www.who.int/cancer/media/news/ cancer-prevention-resolution/en/, (2017) (accessed December 9, 2017).

[21] C. Santini, M. Pellei, V. Gandin, M. Porchia, F. Tisato, C. Marzano, Advances in copper complexes as anticancer agents, Chem. Rev. 114 (2014) 815-862, https:// doi.org/10.1021/cr400135x.

[22] C. Marzano, M. Pellei, F. Tisato, C. Santini, Copper complexes as anticancer agents, Anti Cancer Agents Med. Chem. 9 (2009) 185-211, https://doi.org/10.2174/ 187152009787313837.

[23] I. Iakovidis, I. Delimaris, S.M. Piperakis, Copper and its complexes in medicine: a biochemical approach, Biochem. Mol. Biol. Int. 2011 (2011) 1-13, https://doi.org/ 10.4061/2011/594529.

[24] J.B. Tommasino, F.N.R. Renaud, D. Luneau, G. Pilet, Multi-biofunctional complexes combining antiseptic copper(II) with antibiotic sulfonamide ligands: structural, redox and antibacterial study, Polyhedron 30 (2011) 1663-1670, https://doi.org/ 10.1016/j.poly.2011.03.033.

[25] J.L. García-Giménez, J. Hernández-Gil, A. Martínez-Ruíz, A. Castiñeiras, M. LiuGonzález, F.V. Pallardó, J. Borrás, G. Alzuet Piña, DNA binding, nuclease activity, 
DNA photocleavage and cytotoxic properties of $\mathrm{Cu}(\mathrm{II})$ complexes of N-substituted sulfonamides, J. Inorg. Biochem. 121 (2013) 167-178, https://doi.org/10.1016/j. jinorgbio.2013.01.003.

[26] Bruker, APEX2, SAINT and SADABS, Bruker AXS Inc., Madison, Wisconsin, USA, 2010.

[27] G.M. Sheldrick, Crystal structure refinement with SHELXL, Acta Crystallogr., Sect. C: Cryst. Struct. Commun. 71 (2015) 3-8, https://doi.org/10.1107/ S2053229614024218.

[28] O.V. Dolomanov, L.J. Bourhis, R.J. Gildea, J.A.K. Howard, H. Puschmann, OLEX2: a complete structure solution, refinement and analysis program, J. Appl. Crystallogr. 42 (2009) 339-341, https://doi.org/10.1107/S0021889808042726.

[29] C.F. Macrae, I.J. Bruno, J.A. Chisholm, P.R. Edgington, P. McCabe, E. Pidcock, L. Rodriguez-Monge, R. Taylor, J. van de Streek, P.A. Wood, Mercury CSD 2.0 - new features for the visualization and investigation of crystal structures, J. Appl. Crystallogr. 41 (2008) 466-470, https://doi.org/10.1107/S0021889807067908.

[30] C.R. Groom, I.J. Bruno, M.P. Lightfoot, S.C. Ward, The Cambridge structural database, Acta Crystallogr. B 72 (2016) 171-179, https://doi.org/10.1107/ S2052520616003954.

[31] W. Zhou, X. Wang, M. Hu, C. Zhu, Z. Guo, J. Chu, B.C. Beaudette-Zlatanova, R. Lu, R.K. Blackman, J. Barsoum, K. Koya, Y. Wada, A mitochondrion-targeting copper complex exhibits potent cytotoxicity against cisplatin-resistant tumor cells through multiple mechanisms of action, Chem. Sci. 5 (2014) 2761-2770, https://doi.org/ 10.1039/C4SC00384E.

[32] X. Dong, X. Wang, M. Lin, H. Sun, X. Yang, Z. Guo, Promotive effect of the platinum moiety on the DNA cleavage activity of copper-based artificial nucleases, Inorg. Chem. 49 (2010) 2541-2549, https://doi.org/10.1021/ic100001x.

[33] C.F. Barbas, D.R. Burton, J.K. Scott, G.J. Silverman, Quantitation of DNA and RNA, Cold Spring Harb Protoc 2007 (2007), https://doi.org/10.1101/pdb.ip47 pdb.ip47.

[34] C.G. Ricci, P.A. Netz, Docking studies on DNA-ligand interactions: building and application of a protocol to identify the binding mode, J. Chem. Inf. Model. 49 (2009) 1925-1935, https://doi.org/10.1021/ci9001537.

[35] J.-C. Palomino, A. Martin, M. Camacho, H. Guerra, J. Swings, F. Portaels, Resazurin microtiter assay plate: simple and inexpensive method for detection of drug resistance in Mycobacterium tuberculosis, Antimicrob. Agents Chemother. 46 (2002) 2720-2722, https://doi.org/10.1128/AAC.46.8.2720-2722.2002.

[36] V. Vichai, K. Kirtikara, Sulforhodamine B colorimetric assay for cytotoxicity screening, Nat. Protoc. 1 (2006) 1112-1116, https://doi.org/10.1038/nprot.2006. 179.

[37] A. Monks, D. Scudiero, P. Skehan, R. Shoemaker, K. Paull, D. Vistica, C. Hose, J. Langley, P. Cronise, A. Vaigro-Wolff, M. Gray-Goodrich, H. Campbell, J. Mayo, M. Boyd, Feasibility of a high-flux anticancer drug screen using a diverse panel of cultured human tumor cell lines, J. Natl. Cancer Inst. 83 (1991) 757-766, https:// doi.org/10.1093/jnci/83.11.757.

[38] B. Macías, M.V. Villa, F. Sanz, J. Borrás, M. González-Álvarez, G. Alzuet, Cu(II) complexes with a sulfonamide derived from benzoguanamine. Oxidative cleavage of DNA in the presence of $\mathrm{H}_{2} \mathrm{O}_{2}$ and ascorbate, J. Inorg. Biochem. 99 (2005) 1441-1448, https://doi.org/10.1016/j.jinorgbio.2005.04.001.

[39] I. Beloso, J. Borrás, J. Castro, J.A. García-Vázquez, P. Pérez-Lourido, J. Romero, A. Sousa, Flexidentate behaviour of 2-pyridylsulfonamides - direct electrochemical synthesis and spectroscopic and X-ray characterisation of neutral copper (II) complexes of N-(2-pyridyl)sulfonamides, Eur. J. Inorg. Chem. 2004 (2004) 635-645, https://doi.org/10.1002/ejic.200300338.

[40] F. Pan, I. Kalf, U. Englert, Bis[4-amino-N-(pyrimidin-2-yl)benzenesulfonamido] diamminecopper(II): aqua or ammine ligands? Acta Crystallogr. C 69 (2013) 1221-1224, https://doi.org/10.1107/S0108270113025948.

[41] A. Pascual-Álvarez, T. Topala, F. Estevan, F. Sanz, G. Alzuet-Piña, Photoinduced and self-activated nuclease activity of copper(II) complexes with N-(Quinolin-8-yl) quinolin-8-sulfonamide - DNA and bovine serum albumin binding, Eur. J. Inorg. Chem. 2016 (2016) 982-994, https://doi.org/10.1002/ejic.201501469.

[42] F.H. Allen, D.G. Watson, L. Brammer, A.G. Orpen, R. Taylor, International tables for crystallography. volume C: mathematical physical and chemical tables, Acta
Crystallogr. A 49 (1993) 371-373, https://doi.org/10.1107/S0108767393099969.

[43] C. Janiak, A critical account on $\pi-\pi$ stacking in metal complexes with aromatic nitrogen-containing ligands, J. Chem. Soc. Dalton Trans. (2000) 3885-3896, https://doi.org/10.1039/b003010o.

[44] J.M. Veal, K. Merchant, R.L. Rill, The influence of reducing agent and 1,10-phenanthroline concentration on DNA cleavage by phenanthroline + copper, Nucleic Acids Res. 19 (1991) 3383-3388.

[45] C.H. Chen, D.S. Sigman, Nuclease activity of 1,10-phenanthroline-copper: sequence-specific targeting, Proc. Natl. Acad. Sci. 83 (1986) 7147-7151.

[46] A. Prisecaru, V. McKee, O. Howe, G. Rochford, M. McCann, J. Colleran, M. Pour, N. Barron, N. Gathergood, A. Kellett, Regulating bioactivity of $\mathrm{Cu}^{2+}$ Bis-1,10phenanthroline artificial metallonucleases with sterically functionalized pendant carboxylates, J. Med. Chem. 56 (2013) 8599-8615, https://doi.org/10.1021/ jm401465m.

[47] C. Slator, N. Barron, O. Howe, A. Kellett, [Cu(o-phthalate)(phenanthroline)] exhibits unique superoxide-mediated NCI-60 chemotherapeutic action through genomic DNA damage and mitochondrial dysfunction, ACS Chem. Biol. 11 (2016) 159-171, https://doi.org/10.1021/acschembio.5b00513.

[48] S.Y. Tsang, S.C. Tam, I. Bremner, M.J. Burkitt, Copper-1,10-phenanthroline induces internucleosomal DNA fragmentation in HepG2 cells, resulting from direct oxidation by the hydroxyl radical, Biochem. J. 317 (1996) 13-16.

[49] M. Satterfield, J.S. Brodbelt, Relative binding energies of gas-phase pyridyl ligand/ metal complexes by energy-variable collisionally activated dissociation in a quadrupole ion trap, Inorg. Chem. 40 (2001) 5393-5400, https://doi.org/10.1021/ ic010356r.

[50] M.M.T. Khan, A.E. Martell, Metal ion and metal chelate catalyzed oxidation of ascorbic acid by molecular oxygen. I. Cupric and ferric ion catalyzed oxidation, J. Am. Chem. Soc. 89 (1967) 4176-4185, https://doi.org/10.1021/ja00992a036.

[51] J. Kypr, I. Kejnovská, D. Renčiuk, M. Vorlíčková, Circular dichroism and conformational polymorphism of DNA, Nucleic Acids Res. 37 (2009) 1713-1725, https://doi.org/10.1093/nar/gkp026.

[52] L. Becco, A. Rodríguez, M.E. Bravo, M.J. Prieto, L. Ruiz-Azuara, B. Garat, V. Moreno, D. Gambino, New achievements on biological aspects of copper complexes Casiopeínas ${ }^{\oplus}$ : interaction with DNA and proteins and anti-Trypanosoma cruzi activity, J. Inorg. Biochem. 109 (2012) 49-56, https://doi.org/10.1016/j.jinorgbio. 2012.01.010.

[53] S. Kathiresan, S. Mugesh, J. Annaraj, M. Murugan, Mixed-ligand copper(II) Schiff base complexes: the vital role of co-ligands in DNA/protein interactions and cytotoxicity, New J. Chem. 41 (2017) 1267-1283, https://doi.org/10.1039/ C6NJ03501A.

[54] B.M. Zeglis, V.C. Pierre, J.K. Barton, Metallo-intercalators and metallo-insertors, Chem. Commun. 7345 (4565) (2007), https://doi.org/10.1039/b710949k.

[55] A.R. Barbosa, K.R. Caleffi-Ferracioli, C.Q.F. Leite, J.C. García-Ramos, Y. ToledanoMagaña, L. Ruiz-Azuara, V.L.D. Siqueira, F.R. Pavan, R.F. Cardoso, Potential of Casiopeínas ${ }^{\circledR}$ copper complexes and antituberculosis drug combination against Mycobacterium tuberculosis, Chemotherapy 61 (2016) 249-255, https://doi.org/10. $1159 / 000443496$.

[56] J. do Couto Almeida, I.M. Marzano, M. Pivatto, N.P. Lopes, A.M. Da Costa Ferreira F.R. Pavan, I.C. Silva, E.C. Pereira-Maia, G. Von Poelhsitz, W. Guerra, Synthesis, cytotoxic and antitubercular activities of copper(II) complexes with heterocyclic bases and 3-hydroxypicolinic acid, Inorg. Chim. Acta 446 (2016) 87-92, https:// doi.org/10.1016/j.ica.2016.03.005.

[57] P. Forgacs, N.L. Wengenack, L. Hall, S.K. Zimmerman, M.L. Silverman, G.D. Roberts, Tuberculosis and trimethoprim-sulfamethoxazole, Antimicrob. Agents Chemother. 53 (2009) 4789-4793, https://doi.org/10.1128/AAC.01658-08.

[58] R.H. Shoemaker, The NCI60 human tumour cell line anticancer drug screen, Nat. Rev. Cancer 6 (2006) 813-823, https://doi.org/10.1038/nrc1951.

[59] C.H. Ng, S.M. Kong, Y.L. Tiong, M.J. Maah, N. Sukram, M. Ahmad, A.S.B. Khoo, Selective anticancer copper(II)-mixed ligand complexes: targeting of ROS and proteasomes, Metallomics 6 (2014) 892-906, https://doi.org/10.1039/ C3MT00276D. 